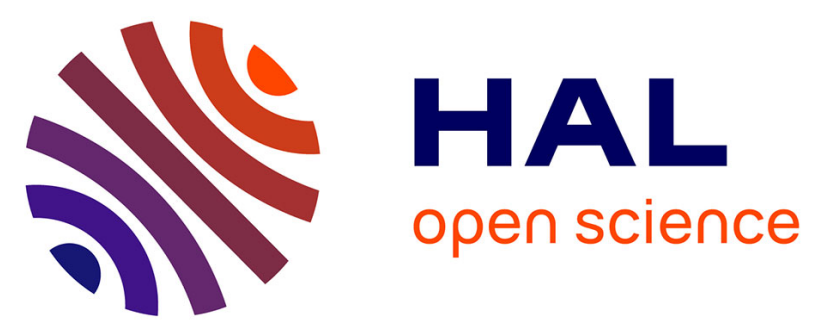

\title{
The role of the south-western Alps as a unidirectional corridor for Mediterranean brown trout (Salmo trutta complex) lineages
}

\author{
Andrea Splendiani, Patrick Berrebi, Christelle Tougard, Tommaso Righi, \\ Nathalie Reynaud, Tatiana Fioravanti, Paolo Lo Conte, Delmastro Giovanni \\ B, Marco Baltieri, Luca Ciuffardi, et al.
}

\section{To cite this version:}

Andrea Splendiani, Patrick Berrebi, Christelle Tougard, Tommaso Righi, Nathalie Reynaud, et al.. The role of the south-western Alps as a unidirectional corridor for Mediterranean brown trout (Salmo trutta complex) lineages. Biological Journal of the Linnean Society, 2020, 10.1093/biolinnean/blaa125 . hal-03032062

\section{HAL Id: hal-03032062 \\ https://hal.umontpellier.fr/hal-03032062}

Submitted on 1 Dec 2020

HAL is a multi-disciplinary open access archive for the deposit and dissemination of scientific research documents, whether they are published or not. The documents may come from teaching and research institutions in France or abroad, or from public or private research centers.
L'archive ouverte pluridisciplinaire HAL, est destinée au dépôt et à la diffusion de documents scientifiques de niveau recherche, publiés ou non, émanant des établissements d'enseignement et de recherche français ou étrangers, des laboratoires publics ou privés. 
1 The Role of the south-western Alps as a unidirectional corridor for

2 Mediterranean brown trout (Salmo trutta complex) lineages

3 ANDREA SPLENDIANI ${ }^{1}$, PATRICK BERREBI ${ }^{2-3}$, CHRISTELLE TOUGARD $^{3}$, TOMMASO RIGHI ${ }^{1}$, 4 NATHALIE REYNAUD ${ }^{3}$, TATIANA FIORAVANTI ${ }^{1}$, PAOLO LO CONTE ${ }^{4}$, GIOVANNI B. 5 DELMASTRO $^{5}$, MARCO BALTIERI ${ }^{6}$, LUCA CIUFFARDI ${ }^{7}$, ALESSANDRO CANDIOTTO $^{8}$, ANDREA SABATINI ${ }^{9}$, VINCENZO CAPUTO BARUCCHI $^{1 *}$

7 'Dipartimento di Scienze della Vita e dell'Ambiente, Università Politecnica delle Marche, via Brecce 8 Bianche, 60100 Ancona, Italy.

$9 \quad{ }^{2}$ Genome - R\&D, 697 avenue de Lunel, 34400 Saint-Just, France.

${ }^{3}$ ISEM, Université de Montpellier, CNRS, IRD, EPHE, Montpellier, France.

${ }^{4}$ Città Metropolitana di Torino, Funzione Specializzata Tutela Fauna e Flora, C.so Inghilterra 7, 10138 Torino, Italy.

${ }^{5}$ Museo Civico di Storia Naturale, Laboratorio di Ittiologia e Biol. Acque, Via San Francesco di Sales 188, 10022 Carmagnola (TO), Italy.

${ }^{6}$ ATAAI-Associazione Tutela Ambienti Acquatici e Ittiofauna, Via Airali 54, 10062 Luserna San Giovanni (TO)

${ }^{7}$ Centro Studi BioNaturalistici s.r.l., Piazza Martinez 6/4, 16143 Genova, Italy.

${ }^{8}$ Ittiologo libero professionista, Via Del Ricetto 6, Predosa, (AL), 15077, Italy

${ }^{9}$ Department of Life and Environmental Science, University of Cagliari, 09126, Cagliari, Italy.

*corresponding author : Vincenzo Caputo Barucchi, v.caputo@univpm.it

Running title: The south-western Alps: a corridor for Salmo trutta

4

\section{5}

\section{6}




\section{Abstract} 3 5

The role of south-western Alps as a corridor for Mediterranean trout (Salmo trutta complex Linnaeus, 1758) was evaluated in order to understand the influence of the last glacial events in shaping the spatial distribution of the genetic diversity of this salmonid. For this, the allochthonous hypothesis of a manmediated French origin (19th century) of the Mediterranean trout inhabiting the Po tributaries in the Italian side of south-western Alps was tested. A total of 412 individuals were analyzed at the mitochondrial control region. The phylogenetic classification was carried out by using a Median-Joining Network analysis. Mismatch pair-wise analysis, molecular dating and Kernel density distribution analysis of the main mitochondrial lineages were evaluated to compare past demographic dynamics with the current spatial distribution of genetic diversity. The main outcomes resulted strongly in agreement with a biogeographic scenario where the south-western Alps acted as a unidirectional corridor that permitted the colonization of the upper Durance (Rhône River basin) by trout from the Po River basin. Therefore, the Mediterranean trout should be considered as native also along the Italian side of the south-western Alps and the allochthonous hypothesis should be rejected.

Key words: Salmo trutta complex, Alpine barrier, ice cover, conservation genetics, biological corridors (1) (1) 51

\section{.} 5 (1) 


\section{INTRODUCTION}

The study of the phylogeographic history of a species represents a fundamental step to understand the factors producing genetic diversity both within and among species, with particular reference to the role played by past environmental and climatic changes in shaping high levels of genetic complexity as well as their current spatial distribution (Purvis \& Hector, 2000). The reconstruction of the recent evolutionary history of an organism is therefore essential to set-up concrete management and conservation actions aiming at protecting its evolutionary potential (Losos et al., 2013). This is particularly true for those organisms impacted by socio-economic interests, where conservation induces conflict with commercial interests (Redpath et al., 2013). In addition, the tentative to state the natural occurrence of an organism on the basis of phylogenetic studies could be made difficult by the long history of the human-mediated natural species range alterations, that may act as a confounding factor that adds further complexity in the study of the already complex evolutionary pathway of an organism (Fernández-García et al., 2014; Sanz, 2018).

Although, the human ability in shaping plant and animal distribution is rooted in ancient culture and traditions (Larson \& Fuller, 2014), nowadays, human-mediated transport beyond biogeographic barriers has led to the introduction and establishment of alien species (sometimes invasive) in new regions worldwide (Shackleton et al., 2019; Berrebi et al., 2020). About freshwater fish, the first written historical records date back the major human-mediated introductions at Roman time and successively at medieval period (Sønstebø, Borgstrøm, \& Heun, 2007; Miró \& Ventura, 2013). Basically, the above ancient freshwater fish translocations were promoted by food purposes, whereas, nowadays, freshwater fish represents one of the most important group of animals introduced for sport purposes worldwide (Leprieur et al., 2008). In particular, brown trout (Salmo trutta complex) is listed as the 100 of the world's worst invasive alien species (Global Invasive Species Database [2019], downloaded from http://193.206.192.138/gisd/100 worst.php on 13-03-2019). At the same time, its natural diversity is imperilled in much of its native range (Budy et al., 2013).

The Italian IUCN red list of vertebrates (Rondinini et al., 2013) classified its conservation status as near threatened, and the French red list (IUCN, 2010) considers the trout status as low concern. It is probably wildly optimistic statements considering that along the Apennine chain less than $3 \%$ of native populations were free of genetic introgressive hybridization with Atlantic genes of domestic origin (Splendiani et al., 2016a). Further, in the Alpine area, its conservation value appears at least chaotic. The brown trout (regardless of its phylogenetic origin) is "on paper" considered as allochthonous in the Piemonte Region and native in the neighbouring Lombardia Region (based on Regional lists of freshwater fishes). In addition, the AIIAD (Italian Association of Freshwater Fish Ichthyologists) guideline for Italian salmonid management proposes to adopt a passive conservation approach for the putative native populations of south-western Alps (Zanetti, Nonnis Marzano \& Lorenzoni 2013). Based on the opinions expressed in this document, the 
Mediterranean trout populations recognizable in this region should be the consequence of historical humanmediated translocations from the Rhône River basin to the Po River basin. The reasons of these trout translocations would be related with the well-known passion for trout fishing of the Queen Elena of Italy (1873 - 1952) (e.g., Siccardi, 1996). Unfortunately, in the above AIIAD document, there is no citation of historical records to sustain this hypothesis. On the contrary, bibliographic records collected in the Geographic dictionary of the Sardinian State (Casalis, 1833, 1852), evidenced a widespread presence of brown trout in the occidental Alps long before Elena's reign (1900-1946). Interesting, as far as it is known, there are no pieces of evidence of trout translocations from France to Italy, taking into account the above historical literature. On the other hand, historical translocation of freshwater fish across the Alps have been well documented, as the case of the historical $\left(16^{\text {th }}\right.$ century) translocation of Salvelinus alpinus from Austria to Trentino Alto Adige Region (Italy) (Tiberti \& Splendiani, 2019).

Here, a comprehensive molecular data set is used to describe wild Mediterranean brown trout population genetic diversity encompassing from the Rhône River basin to the Po River basin to try to reach several objectives. The first aim of the present study is to provide, for the first time, a focus on brown trout mitochondrial DNA (mtDNA) genetic diversity distribution along a putative contact zone between several lineages of this species complex. The second aim is to find solid hypotheses to correlate spatial distribution of genetic diversity with the main evolutionary forces that could have played a role in shaping the Mediterranean brown trout lineage distribution observed in the study area, that are: i) effects of the last glacial maximum (LGM, that are, ice cover extension, effects of ice flow pattern during deglaciation episodes, localization of glacial refuges, etc), and ii) the role of geomorphologic and hydrogeological characteristics of the mountain relief in the south-western Alps in shaping genetic diversity. Finally, the third aim is to test the hypothesis of non autochthony proposed by AIIAD and as a consequence provide recommendations to preserve, in a rational manner, what remains of the native genetic diversity of brown trout in south-western Alps watercourses.

\section{MATERIAL AND METHODS}

\section{SAMPLING DESIGN}

The $S$. trutta complex is characterized by a puzzling pattern of geographical forms probably underlying the taxonomic inflation reported in literature with the description of nearly 50 Salmo species (Tougard et al., 2018). The description of the native trout taxa previously identified (e.g., Kottelat \& Freyof, 2007) in the study area have been summarised in Table S1. In this study, for practical reasons, the following terms will be used hereafter: (1) "marble trout" for S. marmoratus specimens (generally fixed for MA haplotypes), (2) "native brown trout" for the individuals showing both a fario phenotype and native haplotypes of the Mediterranean area (that are, haplotypes belonging to the lineages AD, ME or MA), (3) "Lake Garda Carpione" to indicate S. carpio specimens and (4) "Atlantic brown trout" to indicate S. trutta specimens hosting domestic and non-native haplotypes (AT lineage). The sampling efforts were mainly focused along 
the south-western Alps, as for example, i) in the upper Durance, that belongs to the Rhône basin, but is located adjacent to the Po River basin along the French side of the south-western Alps, and ii) along the main sub-basins of the Po River basin, as regards the Italian side of the south-western Alps. For comparisons, further samples from other sites of the Rhône River basin and from neighbour minor Mediterranean independent rivers were also included, for example, the rivers Var, Loup, Roya and Sansobbia. The sampling size ranged from 4 to 24 with a mean value of 10 trout per sample. The total number of analysed $S$. trutta was 412 specimens that were collected from 42 sites (Figure 1, Table 1).

\section{DNA EXTRACTION}

From each fish, a small fin clip was removed and conserved in 95\% ethanol until DNA extraction. Due to the union of genetic data obtained from two different laboratories (i.e., from the ISEM, Université de Montpellier and from the DiSVA, Università Politecnica delle Marche, hereafter, respectively, Lab.1 and Lab. 2), total genomic DNA was extracted using two methods. The first one (Lab. 1) consisted in a Chelex/proteinase K-based protocol described by Estoup, Largiader, Perrot \& Chourrot (1996). A small piece of fin was incubated overnight at $56^{\circ} \mathrm{C}$ in $195 \mu 1$ of $5 \%$ Chelex 100 Resin (Biorad) solution containing $50 \mathrm{mM}$ of Tris-HCL (pH 7) and $500 \mu \mathrm{g} / \mathrm{ml}$ of proteinase K. Samples were then incubated at $95^{\circ} \mathrm{C}$ for $10 \mathrm{~min}$ before centrifugation at $3500 \mathrm{~g}$ for $5 \mathrm{~min}$. Supernatants were recovered and frozen at $-20^{\circ} \mathrm{C}$ until required for use. In the second method (Lab. 2), total genomic DNA was extracted using an automated DNA extractor (MagCore ${ }^{\circledR}$ Automated Nucleic acid Extractor in combination with the Genomic DNA Tissue Kit 401).

In Lab. 1, the mtDNA control region (CR) was amplified by PCR using the PST (5'CCCAAAGCTAAAATTCTAAAT-3') and FST (5'-GCTTTAGTTAAGCTACGC-3') primers (Cortey \& García-Marín, 2002). Each $50 \mu \mathrm{L}$ reaction included $0.4 \mu \mathrm{M}$ of each primer (Eurofins MWG Operon), dNTP ( $2 \mathrm{mM}$ each), $2 \mathrm{mM}$ of $\mathrm{MgCl} 2,10 \mu \mathrm{L}$ of $59 \mathrm{PCR}$ buffer, $1 \mathrm{U}$ of Taq polymerase (GoTaq ${ }^{\circledR}$ Promega), and about $50 \mathrm{ng}$ of genomic DNA. The PCR conditions included initial denaturation $\left(95^{\circ} \mathrm{C}, 5 \mathrm{~min}\right)$, followed by 30 cycles of strand denaturation $\left(94^{\circ} \mathrm{C}, 1 \mathrm{~min}\right)$, primer annealing $\left(52^{\circ} \mathrm{C}, 1 \mathrm{~min}\right)$, and DNA extension $\left(72^{\circ} \mathrm{C}\right.$, $1 \mathrm{~min})$ cycles, and then by a final extension $\left(72^{\circ} \mathrm{C}, 5 \mathrm{~min}\right)$. All PCR amplifications were performed in Eppendorf Mastercycler thermocyclers. The amplified DNA fragments were run on a $0.8 \%$ agarose gel to verify the amplification efficiency. The amplified products were purified and sequenced in both directions to confirm the polymorphic sites in an ABIPRISM 3130/xl/sequencer (Applied Biosystems). In Lab. 2, the mtDNA CR was PCR-amplified according to Bernatchez \& Danzmann (1993) (primer sequences: LN20, 5' ACCACTAGCACCCAAAGCTA; HN20, 5' GTGTTATGCTTTAGTTAAAGC). Screening of mtDNA genetic variability was conducted through Single-Strand Conformation Polymorphism (SSCP) analysis. Because shorter fragments are better suited for detection of mutations in SSCP gels (Hayashi, 1991), the CR PCR products of $c .1000 \mathrm{bp}$ were first digested with AluI restriction enzyme and then run on a nondenaturing polyacrylamide gel for 12-h at $5 \mathrm{~W}$ in a cool chamber. Finally, the non-digested segment of $c$. $1000 \mathrm{bp}$ was sequenced in a sub-sample of individuals with the same SSCP profile (that is, three-four trout per each SSCP morph detected). 
167

168

169

170

171

172

173

174

175

176

177

178

179

180

181

182

183

184

185

186

187

188

189

190

191

192

193

194

195

196

197

198

199

200

201

The mtDNA CR sequences were aligned using Clustal W (Larkin et al., 2007). In order to assign the sequence haplotypes observed in this study to each of the main brown trout mtDNA lineages, several reference $S$. trutta CR sequences were downloaded from GenBank (belonging to the mtDNA lineages ME, $\mathrm{AD}, \mathrm{MA}$ and $\mathrm{AT}$ ) (see Table S2 for more details). The genealogical relationship among haplotypes was depicted using a Median-Joining Network (Bandelt, Forster, \& Rohl, 1994) constructed using Network 5 (Fluxus Technology Ltd., www.fluxus-engineering.com), considering also gaps and missing nucleotides. The $\varepsilon$ parameter was set to zero. Historical demography inferences were drawn from three neutrality tests implemented in DnaSP 6 (Rozas et al., 2017): i) Fu's $F_{S}$ (Fu, 1997), ii) Tajima's $D$ (Tajima, 1989) and iii) $R_{2}$ (Ramos-Onsins \& Rozas, 2002), and from mismatch distribution analysis by using Arlequin 3.5 (Excoffier \& Lischer, 2010). Briefly, a significantly negative Tajima's $D$ and $F s$, and a significantly positive $R_{2}$ indicate a scenario of demographic expansion. In the mismatch analysis, a curve displaying the observed distribution of pair-wise differences within each lineage is compared to an expected curve under a model of population growth-decline. Generally, a curve with a single peak associated with a low number of pair-wise differences indicates expansion, while a curve with two or multiple peaks indicates stability. Differences between observed and expected pair-wise mismatch distribution were evaluated using the sum of squared deviations (SSD) and the raggedness index (r) as implemented in Arlequin 3.5.

The estimation of time to the most recent ancestor (TMRCA) of the AD, ME and MA lineages was carried out with a Bayesian coalescent analysis using BEAST 1.10.4 (Suchard et al., 2018) under a HKI + I model as inferred by using jModeltest (Posada, 2008). We adopted two fixed values with a normal prior distribution (0.75 - 1\%) of divergence rates (e.g., Sanz, 2018 and references therein), and taking into account that we were interested in the estimation of the separation time between the Mediterranean lineages AD, ME and MA, we adopted the basic strict clock model, as implemented in BEAST, because, potentially outperforming for trees with shallow roots (Brown \& Yang, 2011). The strict molecular clock was used in combination with three coalescent models (constant size, exponential growth, expansion growth). To determine the best fitting model of the data (Brandley, Schmitz, \& Reeder, 2005), a modified Akaike Information Criterion (AICM) as provided in TRACER 1.6 (Rambaut et al., 2018) was used. The models were run five times for fifty million generation with a $10 \%$ burn-in stage. Markov chain convergence was checked visually by the inspection of the traces, while the run stability was measured using the effective sample size (ESS $>200$ for all parameters) using Tracer. Results of the independent convergent runs were combined with LogCombiner v 1.10.4 (auxiliary program implemented in the BEAST package) to estimate TMRCA and $95 \%$ highest probability density intervals (HPD). A consensus tree was then generated using TreeAnnotator 1.10.4 (auxiliary program implemented in the BEAST package) with the following options: maximum clade credibility and mean node heights.

Hierarchical analysis of molecular variance (AMOVA) was used to test how the effects of the last glacial events, occurred in the study area, could explain the current spatial genetic distribution. Groupings included: 
i) Rhône samples vs Po samples and ii) Rhône samples vs Po and Durance samples. This latter grouping was set-up to test the hypothesis of a recent post-glacial origin of brown trout samples from upper Durance related to slope failure phenomena due to last deglaciation events. The above tests were carried out by using Arlequin 3.5, using conventional F-statistics and testing the statistical significance of the tests with 5,000 permutations.

To depict the biogeographic scenarios underlying the observed haplotype spatial distribution, the mtDNA lineage distribution observed in each population was both analysed by mapping pie charts geographically and using Kernel density (KD) analysis along an elevation, longitudinal and latitudinal gradient. The KD analysis was conducted partitioning the samples as i) samples from the Rhône River basin and ii) samples from the Po River basin. For these tests, brown trout samples were grouped in the following categories: i) samples fixed for AD haplotypes, ii) samples fixed for ME haplotypes, iii) samples fixed for MA haplotypes and mixed samples, iv) samples sharing AD and ME haplotypes, v) AD-MA, vi) ME-MA and vi) AD-MEMA. The rational of the above partitioning was to verify if haplotype distribution can match with plausible scenarios of extinction and recolonization events connected with the environmental changes occurred during the last glacial maximum in the south-western Alps. The KD analysis was carried out by using the density function in R software (R Development Core Team, 2017).

\section{RESULTS}

\section{HAPLOTYPE CLASSIFICATION}

Before starting with sequence analyses, the PolyT region of the CR was considered of a constant length of $14 \mathrm{bp}$ in all sequences. In fact, such region is likely to be unstable and thus characterized by a high mutation rate, showing frequent $14-\mathrm{T}$ variants. In this circumstance, sequence stretch length identity, could be the mere consequence of homoplasy and would not represent a real phylogenetic signal. On the whole, an alignment of 981 bp was obtained, from which 21 haplotypes emerged (Table 2). The observed haplotypes belonged to four main mtDNA lineages: AD, ME, MA and AT (sensu Bernatchez et al., 1992 or Bernatchez, 2001). The AD lineage was represented by three haplotypes: ADporh-1 and ADrh-1, observed for the first time in this study (GenBank accession numbers, respectively, MK948034 and MK948035) and ADcs-1 already described in literature (Cortey, Pla \& García-Marín, 2004). As far for the ME lineage, seven haplotypes were observed, two of which already detected in other studies, that are: MEcs-1 and MEcs-15 (e.g., Cortey et al., 2004) and the other five were detected for the first time in this study and named as follow: MEcs-28 to MEcs-32 (from MK948029 to MK948033). The MA lineage displayed a new haplotype named MAsl-1 (MK948036), and three mtDNA variants already detected in previous studies, namely Ma2a, Ma2b and Ma2c (Meraner, Baric, Pelster, \& Dalla Via, 2007; Meraner, Gratton, Baraldi \& Gandolfi, 2013). Finally, the Atlantic lineage was represented by six haplotypes, five of them were already detected in Mediterranean rivers and classified as haplotypes of hatchery origin, that are: haplotype 1 to haplotype 4 (Cortey \& García-Marín, 2002) and the haplotype At1e, (Meraner et al., 2007), while one haplotype was 
described for the first time in this study (haplotype 3b, MK948037). This latter haplotype should be also considered of hatchery origin due to high similarity with the domestic variant haplotype 3 (Table 2, Figure 2).

\section{HAPLOTYPE SPATIAL DISTRIBUTION}

The ME lineage dominated in the Rhône River drainage and in the other minor French rivers included in this study. The most common ME haplotype was MEcs-1, the rest of the ME haplotypes (MEcs-28 - 32) was endemic of French Mediterranean rivers. On the other hand, within the Po River drainage and in the Sansobbia River, the ME lineage was represented by the haplotype MEcs-1.

The AD lineage was quite common in the Po River drainage, however, the ancestral haplotype of this lineage (ADcs-1, see Figure 2) was observed only in a sole trout (in sample GIU, Po River basin). However, in other studies within the Po River drainage, the haplotype ADcs-1 was detected in both $19^{\text {th }}$ century trout (Splendiani et al 2017), as well as in recent samples (Gratton et al., 2014; Stefani, Anzani, \& Marieni, 2019). Toward the west part of the Po River drainage, the haplotype ADporh-1 was newly detected (one Mutational Step from ADcs-1). This latter haplotype presented a spatial distribution confined to the upper reaches of both upper Durance River (Rhône basin) and Po River along a transect of the south-western Alps extended from the Cottian to the Maritime Alps (Figure 1 and Table 2, see also next paragraph). Finally, the haplotype ADrh-1 consistently with its position in the Median-Joining Network (one MS from the haplotype ADporh1) was found only in the western part of the Rhône River drainage, in the Petit Buëch stream.

The MA haplotypes were found only within the Po River drainages. The most common haplotype detected for this lineage was Ma2b. This mtDNA variant occupied a central position within the MA lineage (Figure 2). In line with its haplotype network position, this haplotype was observed elsewhere within the Po River drainages in both modern (Meraner et al., 2007, 2013) and museum specimens (from $19^{\text {th }}$ century, e.g., Splendiani et al., 2017).

Finally, as expected, the AT haplotypes formed a separate cluster in the Median-Joining Network (Figure 2). These non-native haplotypes for the Mediterranean area showed an evident greater abundance within the Italian samples (Table 2, Figure 1). Here, a mean value of AT haplotypes of $38 \%$ and a maximum value of $70 \%$ (in the locality MAIb) were observed. In four localities (TRO, RIP, FER and GES), the AT haplotypes were not observed. In the French samples, the AT haplotypes were observed only in two localities out of 21, GLU $(60 \%)$ and ROY (20\%).

\section{MISMATCH ANALYSIS AND DIVERGENCE TIME ESTIMATES}

Mismatch distribution analysis indicated (see Table S3 and Figure S1) a scenario consistent with a model of demographic expansion (Excoffier, 2004) for the brown trout mtDNA lineages ME and AD and a stable demographic trend for the lineage MA. 
The AICM suggested that a strict clock under a constant size coalescent model best-fits our data. The TMRCA estimations placed the origin of the AD lineage from 278,000 (95\% HPD 170,000 - 391,000) to 212,000 (95\% HPD 129,000 - 298,000) years ago by adopting, respectively, a substitution rate of 0.75 and $1 \%$, the origin of the ME lineage from 267,000 (95\% HPD 166,000-372,000) to 191,000 (95\% HPD $122,000-265,000)$ years ago, and the origin of the MA lineage from 122,000 (95\% HPD 172,000-205,000) to 117,000 (95\% HPD 51,000-193,000) years ago (see Table S4). MA lineage appears so as the youngest one. Finally, the origin of the AD branch composed by the haplotypes ADporh-1 and ADrh-1 was placed around 151,000 (95\% HPD 11,000-99,000) and 120,000 (95\% HPD 16,000-86,000) years.

With both two grouping options (Rhône samples vs Po Samples and Rhône samples vs Durance and Po samples), the AMOVA analyses showed that most of the genetic variation was explained at the within population level (53.26 and 51.62\%, respectively) and among populations within group level (33.84 and $26.84 \%$, respectively). However, the AMOVA analyses showed also that grouping the Durance samples within the Po River group explained much more genetic variation $(21.54 \%)$ than grouping the Durance within its main river basin (i.e., the Rhône River basin) (14.92 \%). In both cases, the statistical significance of the source of variation represented among groups was highly significant $(P=0.0000)$.

\section{KERNEL DENSITY (KD) BROWN TROUT LINEAGE DISTRIBUTION}

Within the Rhône River drainage, the highest density of samples characterized by the sole presence of ME haplotypes was found between 4.5 - 5.5 E longitudes (Figure 3A). Unfortunately, only one sample was characterized by the sole presence of $\mathrm{AD}$ haplotypes (BUË), therefore, KD analysis was not applicable in this case. On the contrary, the rest of the Rhône samples (i.e., samples from the Durance sub-basin) were composed by a mixture of $\mathrm{AD}$ and ME haplotypes. In this study, a total of 91 trouts originated from the Rhône River basin in France, among them, 31 specimens showed the AD haplotypes. All these latter trouts came from the Durance sub-basin (samples BUË, BIA, CLA, UBA and GUI, see Table 2). The last two rivers (UBA and GUI) are flowing in France directly from the France-Italy boundary. This kind of populations peaked around 7.0 E longitude, corresponding with the upper part of the Durance River (Figure 3A). When KD was carried out to relate brown trout lineages distribution with elevation, a similar net separation between different categories of samples was observed. For example, in the Rhône River, populations fixed for ME haplotypes were most abundant around $0-500 \mathrm{~m}$ (Figure 3B), whereas admixed populations (AD - ME) showed higher values of probability between $1500-2000 \mathrm{~m}$. Within the Po River drainage, the different categories of populations defined based on mtDNA lineage composition, appeared clearly stratified along an altitudinal cline. Pure ME populations were detected only in one case (BAR, Tanaro River, Ligurian Apennine). Admixed AD - ME populations were, however, the most common and reached a density peak around $1600-2000 \mathrm{~m}$. Pure AD populations peaked slightly lower, around $1400 \mathrm{~m}$ 
admixed MA - AD brown trout samples. Further downstream (c. $450 \mathrm{~m})$, pure marble trout samples (MA) were abundant (data from Giuffra et al., 1994). Finally, a pattern of brown trout mtDNA lineage density distribution along the south-western Alps was also evident along a latitudinal gradient (Figure 3D). For example, pure AD samples appeared most abundant around $44.0-44.5 \mathrm{~N}$, roughly corresponding with the Maritime Alps (Italian side), while admixed populations (AD - ME) peaked around 45.0 N (i.e., Cottian Alps).

\section{DISCUSSION}

In the following chapters of this study, a comprehensive phylogeographic analysis of brown trout populations inhabiting adjacent tributaries of the Rhône and Po River basins is proposed for the first time. Based on the biogeographic scenario reconstructed, the allochthonous hypothesis proposed by the Italian Association of Freshwater Fish Ichthyologists (Zanetti et al., 2013) about Mediterranean brown trout populations inhabiting the south-western Po tributaries was evaluated. Substantially, the shared haplotype diversity ( $\mathrm{AD}$ and ME haplotypes) observed along the two sides of the south-western Alps and, at the same time, the presence of an important ice cover along the western part of the Rhône basin (i.e., the Durance glacier) during the glacial phases, incompatible with the presence of freshwater fish, suggest that native brown trout survived the adverse phases of the upper Pleistocene just in the tributaries of the south-western Po basin. Probably, the erosional events related with the deglaciation phenomena permitted the opening of a biological corridor for brown trout from the Po basin toward the Rhône basin.

\section{THE ORIGIN OF THE S. TRUTTA ME LINEAGE IN THE STUDY AREA}

According to previous studies (Cortey et al., 2004; Vera et al., 2019), the Iberian Peninsula would represent the ideal candidate as the centre of the origin of the ME lineage (e.g., Sanz, 2018). However, the ME haplotype diversity detected in the present study partially contrast with the above hypothesis. Within the Rhône River basin and neighbour rivers, five new ME haplotypes were detected. This fact appears in accordance with a western Mediterranean origin of the ME lineage as previously proposed (e.g., Bernatchez, 2001; Cortey et al., 2004; Oliver, 2014) but also suggests that the Rhône basin area acted as an important evolutionary centre for ME genetic diversity.

Although, the use of the sole mitochondrial control region could be taken into account with caution for inferring isolation time accurately (Schenekar, Lerceteau-Köhler, \& Weiss, 2014), an attempt was, however, tried in this study. In this sense, it is interesting to indicate that the pre-defined divergence rates of $0.75-1 \%$ adopted in this study designed a time since expansion of the major Mediterranean lineages (ME, AD and MA) in accordance with their altitudinal distribution observed in the study area (see below).

The TMRCA analysis suggest a main expansion of the ME lineage around 191,000-267,000 years ago, roughly corresponding with the last (III) Mindel-Riss Interglacial, and resulting slightly more ancient respect previous estimations (Cortey et al., 2004). Pleistocene Interglacial warming periods have been regarded as 
phases of isolation in small headwaters for Mediterranean brown trout populations, thus promoting genetic signatures within lineages (e.g., Sanz, 2018 and references therein). On the other hand, during glaciations, colder climate conditions may have triggered sea-ward migratory tactics in Mediterranean brown trout populations, as highlighted by several paleontological evidences (Muñoz \& Casadevall, 1997; Splendiani et al., 2016b; Splendiani et al., 2020). Therefore, thanks to a seaward migratory route, the expansion of brown trout in the Mediterranean area was possible. The colonisation of northern Corsica Island by the ME lineage during the last glaciation is an example of this expansion (Gauthier \& Berrebi, 2007). The spatial distribution of the MEcs-1 haplotype suggests a potential eastward dispersion, from the Rhône River outlet to the Var River (SAL, Gulf of Lion) where this haplotype was found and more eastern to the Sansobbia River (SAN, Ligurian Sea) (Figure 1, Table 2). Then, when the ME lineage reached the upper part of the Ligurian rivers, the colonization of the Po River basin was likely possible thanks to river capture events occurred along the Ligurian Apennine chain. This scenario could explain the finding of the MEcs-1 haplotype in the Rio Baracca (BAR, Po River basin, see also Figure 1, Table 2). Interestingly, the role played by the hydrographical captures of the upstream portions of Mediterranean rivers was also proposed in the literature to explain, for example, the exchange of Duero haplotypes between rivers flowing along opposite slope of the Cantabrian mountains (Iberian Peninsula) (Vera et al., 2015), as well as to explain the native occurrence of the Danubian haplotypes within marble trout populations of the Sôca River (Berrebi, Jesenšek, \& Crivelli, 2017). Concerning the study area, the phylogeographic history of the Italian vairone (Telestes muticellus) in populations of west Liguria (Marchetto et al., 2010) could also be explained invoking the presence of biological corridors opened by ancient Mediterranean river captures.

Once reached the Po River basin, it can be reasonably expected that the ME lineage tried to colonize available salmonid habitats. However, when the climate conditions went colder and the Alpine ice cover expanded, this lineage survived only in refuge areas as, for example, in south-western Alps. Milder conditions in this part of the Alpine chain and the absence of other brown trout lineages may have permitted the colonization of the upper reaches of the western Alps by the MEcs-1 haplotype (see the Kernel density analysis in the Results section and Figure 3).

\section{THE ORIGIN OF THE S. TRUTTA AD LINEAGE IN THE STUDY AREA}

The Adriatic-Balkan part of the Mediterranean basin is considered the centre of the origin of the AD lineage (Sanz, 2018). The main expansion of the AD lineage seems to take place around 267,000-212,000 year ago and therefore nearly simultaneous with the last expansion proposed above for the ME lineage. Although, as already stressed, divergence estimations should be interpreted with caution, mainly with regard to the absolute date of expansion values, more reliable, on the contrary, appears the simultaneous time of expansion of the $\mathrm{AD}$ and ME lineages observed in this study. The simultaneous expansion of these two lineages fits well with both their similar peri-Mediterranean spatial distribution and with their phylogenetic complexity (e.g., Sanz, 2018). 
In north Italy, the central haplotype of the AD lineage (ADcs-1) was observed in two museum specimens (dating back to the end of $19^{\text {th }}$ century) of Lakes Garda and Maggiore and in a modern sample of the Adige Adriatic River (Meraner et al., 2013). According to Splendiani et al. (2016a, 2017), the spatial distribution of the Mediterranean trout genetic diversity in north Italy represents a sort of "map" of the potential Alpine peripheral refuges where brown trout survived during the extreme glacial phases. In addition, the role played by the area of the Lake Garda as an important glacial refuge for the genus Salmo is also evidenced by the detection of two endemic AD and MA haplotypes in Lake Garda Carpione, an endemic trout of this major Italian lake (Gratton et al., 2014) (Figure 2). Further, the finding of a new AD haplotypes (ADporh-1), endemic of the south-western Alps, suggests that also this area could have acted as both an important glacial and interglacial refuge for brown trout. In the south-western Alps' part of the Po River basin, the haplotype ADporh-1 was the sole AD haplotype observed. This haplotype was found as fixed in samples collected around $1000-1500 \mathrm{~m}$ (Figure 3), that is slightly lower than the quote where AD-ME mixed populations peaked. Thus, the observed spatial distribution suggests that the ME lineage colonized first the headwaters of the south-western Po River basin, whereas the AD lineage tried to do the same later. Based on molecular dating analyses, both ME and AD lineages showed a similar divergence time and thus it is hard to explain their different altitudinal distribution. However, the proximity of the south-western Alps to an important centre of origin of the lineage ME, as can be considered the Rhône River basin, could explain why the ME lineage reached the highest sites of the south-western part of the Po River basin first.

The peculiar AD haplotypes detected across the south-western Alps (i.e., ADporh-1 and ADrh-1 haplotypes) probably split from the ADcs-1 ancestor when warmer climate condition promoted phases of isolation. The estimated origin for this $\mathrm{AD}$ branch of c. 151,000 - 120,000 years ago, corresponding approximatively with the Riss-Würm Interglacial. During the warmer phases, brown trout population may have survived in high altitude habitats of the south-western part of the Po River basin. This region would also have been used as refuge during the colder phases (i.e., the Younger Dryas stadial, c. 12,800 and 11,600 years BP) when the rest of the high-altitude Alpine streams was covered by a massive ice cover. Later, at the beginning of the Holocene, the extreme erosional events produced by massive episodes of deglaciation promoted the colonization of the upper Durance basin from the adjacent high altitude brown trout populations survived in the south-western Po streams by river captures (see the next paragraph for more information: The role of the south-western Alps as an asymmetrical biological corridor for brown trout lineages).

The Italian side of the Maritime Alps represented also an isolated refuge. Interestingly, in this region, both the AD-Tyrrh-1, very common elsewhere within the Tyrrhenian watercourses (e.g., Berrebi et al., 2019) and ADcs-11, very common around the Adriatic Sea rivers (Sušnik et al., 2007; Snoj et al., 2009, 2010), haplotypes were not found. Based on the network haplotype topology (Figure 2), we can hypothesized that ADcs-1 colonized first the Po River, and then, during phases of geographic isolation within refugia, new haplotypes, as ADporh-1 within the Maritime Alps refuge and the S. carpio AD haplotypes (ScarAD-1 and 
ScarAD-2), within the Lake Garda refuge, could split. According to Sanz (2018), the AD lineage was characterized by multiple waves of expansions. Successive expansion opportunities were probably used by individuals carrying haplotypes ADcs-11 (around the Adriatic Sea) and AD-Tyrrh-1 around the Tyrrhenian Sea, these latter ones, however, were unable to colonize the Po River as it was already occupied by both brown trout (showing the ADcs-1, ADporh-1 and MEcs-1 haplotypes) and marble trout (showing the Ma2a, Ma2b, Ma2c and MAsl-1 haplotypes).

\section{THE ORIGIN OF THE S. TRUTTA MA LINEAGE OBSERVED IN THE STUDY AREA}

Within the Po River basin, the MA lineage showed an evolutionary pathway like that observed in the case of the AD lineage. For example, in the Lake Garda Carpione, Gratton et al. (2014) exhibited two endemic MA haplotypes (named here ScarMA1 and ScarMA2, see also Figure 2). Further west, in brown trout samples, a new MA haplotype (MAsl-1) was found, although in a sole specimen (Table 2). In this study, the most diffuse MA haplotype detected in the south-western part of the Po River was Ma2b, also common elsewhere in the Po River basin both in native brown trout and Lake Garda Carpione specimens (e.g., Meraner et al., 2007; 2013). However, the most relevant result was represented by the spatial distribution of the MA lineage as detailed below. In this study, the native brown trout samples from the south-western tributaries of the Po River basin, characterized by the sole presence of MA haplotypes, showed an altitudinal range of distribution intermediate between marble trout $(c .450 \mathrm{~m})$ and native brown trout populations characterized by a mix of AD and ME haplotypes (c. $1600-2000 \mathrm{~m})$. Therefore, based on the altitudinal distribution of the MA lineage it could be hypothesized that this lineage tried to reach the upstream thermal refuges for last. This hypothesis seems to accord well with the younger origin of MA lineage respect to ME and AD lineages emerged in this study and proposed also by Oliver (2014). In addition, the altitudinal distribution of the MA lineage appear congruent with the stable or declining demographic scenario emerged by mismatch analysis. The reduced habitat availability could have contrasted the demographic expansion of this lineage (e.g., Lavery et al., 1996; Bernatchez, 2001). Probably, this mtDNA lineage was fixed in marble trout that inhabited the lower part of the Po River basin, then, when climate become warmer, this salmonid tried to reach colder habitats at higher elevations. A similar palaeohistorical scenario was previously proposed (Berrebi et al., 2000) to explain the spatial distribution of both brown trout and marble trout within the Sôca River basin (Slovenia). The detection, in the present study, of only native brown trout phenotypes in samples characterized by the sole presence of MA haplotypes suggests that the contact between brown trout and marble trout occurred within an ecological contact zone (i.e., ecotonal zone) where the parental Mediterranean phenotype outcompeted (e.g., Arnold, 1997). Alternatively, the evolution of habitat preference of the MA lineage for lower river sections could explain its altitudinal distribution observed in the south-western Alps. However, elsewhere, as for example in the Adige River basin, the MA lineage was able to reach, accessible and formerly glaciated, high altitude sites (around $1000-1600 \mathrm{~m}$ ) (Meraner et al., 2007, 2010; Splendiani et al., 2016a). 

CORRIDOR FOR BROWN TROUT LINEAGES

The comparison between the brown trout mtDNA genetic diversity observed along the two sides (east and west) of the south-western Alps highlights the lack of a substantial genetic differentiation between the samples collected in the upper Durance River (Rhône River basin) and the upper reaches of the Po River. Most samples from upper Durance and Po basins were composed by a mixture of the ADporh-1 and MEcs-1 haplotypes (Table 2). The similarity in haplotype composition between the native brown trout populations of the two-opposite sides of the south-western Alps was also supported by the hierarchical analysis of molecular variance (AMOVA). In fact, when the samples of the upper Durance were grouped together with the Po River group, the level of genetic variation explained between groups of populations increased from 14 to $21 \%$, suggesting that the vicariant events between upper Durance and Po brown trout populations occurred recently. In this regard, it is important to note that all the Durance collection sites extended in elevation from 1117 to $2077 \mathrm{~m}$, that is, an altitudinal range occupied by the ice cover during the last glacial maximum (e.g., Figure 1), which implies the arrival of trouts after this period. Interestingly, the private ADrh-1 haplotype, a mtDNA variant distant of one MS only from the haplotype ADporh-1, was detected in the Petit Buëch stream, sited at the margin of the Durance glacier. Here, the milder climate condition of this part of Durance basin could have allowed the maintenance of trout populations and represented a refuge for the haplotype ADporh-1 and the centre of origin for the haplotype ADrh-1.

A possible explanation for the high genetic affinity observed between brown trout samples from the upper Durance and Po River basins could be deducted when taking into account the effects, in terms of fish exchange along the Alpine barrier, provided by the last deglaciation events occurred in the south-western Alps. Likely, the first important factor that has drawn the present geographic structure of trout populations is the spatial distribution of the ice cover during the LGM. During this period, the Durance paleo-glacier was one of the most important Alpine glacier (Cossart, Braucher, Fort, Bourlès, \& Carcaillet, 2008) (Figure 1). On the other hand, along the Italian side of the south-western Alps, the ice cover appeared less extended (Hughes, Woodward, \& Gibbard, 2006; Szövényi et al., 2009) (Figure 1). An explanation for the formation of an unidirectional corridor between the two side of the south-western Alps could be related with the formation of small ephemeral lakes and/or the swelling of connecting streams at the retreating edge of a glacier that may allow watershed crossing and drainage switching by freshwater fish (Waters et al., 2001). This scenario was proposed to explain the colonization of the Lake Geneva (Rhône River basin) by bullhead Cottus gobio migrants from the Rhine River basin during the last glacial retreat (Vonlanthen et al., 2007). Further, also the spatial distribution of the genetic diversity of Galaxias platei in Patagonia along the Andes also represents a similar example showing the role of glacial retreat events in promoting fish migrations across watersheds (Zemlak et al., 2008; Habit et al., 2010). Therefore, a scenario can be suggested where, first, during the colder phases, brown trout survived in the ice-free tributaries of the south-western Alps (i.e., Maritime and Cottian Alps), and second, during the erosional events related to the ice melting (early 
Holocene), an unidirectional corridor opened and permitted the colonization of the empty habitats of the adjacent upper Durance river catchment from the Po watershed. Interestingly, along the south-western Alps, the haplotype MEcs-1 was recently detected (Splendiani et al., 2017) in a museum specimen collected in 1876 in the Lake Mont Cenis (1974 m a.s.1.) (Figure 1), a former small Alpine Lake (since 1921 the lake was artificialized by the construction of a weir) of post-glacial origin belonging to the Dora Riparia River and located near the divide between the Po and Rhone catchments.

Finally, the above scenario could be also proposed to explain the spatial pattern of genetic diversity that has been observed in other freshwater organisms inhabiting the two sides of the south-western Alps. For example, as in the case of the high genetic similarity observed between adjacent populations of Cottus gobio (Šlechtová et al., 2004), or similarly, the lack of genetic differentiation observed between adjacent populations of Austrapotamobius pallipes (Stefani et al., 2011).

\section{TAXONOMIC IMPLICATIONS}

As suggested above, in material and methods section, the main aim of the present study was not related with the attempt to solve the well-known problem of the $S$. trutta complex systematic (Splendiani et al., 2019b). However, the phylogeographic scenario of Mediterranean brown trout that emerged here represents an opportunity to partially face with the above taxonomic issues. The trout from the two sides of the southwestern Alps are traditionally classified into three-four nominal species that we have used here for practical reasons: S. rhodanensis (Rhône River basin) a contested species (Berrebi et al., in prep.), S. cettii (a nonvalid name when used to indicate trout from the Tyrrhenian and Ligurian Sea draining rivers) and $S$. farioides or S. cenerinus (depending on the authors, Adriatic draining rivers) (Figure 1). At mtDNA level, none of the above nominal species showed a genetic distinctiveness able to justify the recognition of different species. For example, the two Ligurian samples (SAN, putative $S$. cettii and BAR, putative $S$. farioides - S. cenerinus) collected from the two sides of the Apennine chain, were both fixed for the haplotype MEcs-1, that is a haplotype quite widespread in the study area, as well in the rest of the Mediterranean rivers. More north, along the contact zone of the Rhône - Po River basins, the samples of the Durance River (putative S. rhodanensis) showed a haplotype composition more similar to that observed along the Italian side (putative S. farioides - S. cenerinus), respect to that shown by rest of the Rhône samples as highlighted by the AMOVA analyses. Obviously, more sound conclusions should be drawn by analysing also nuclear and morphological markers (see Ninua, Tarkhnishvili, \& Gvazava, 2018 for similar arumentations). These preliminary results however refute the traditional taxonomic position adopted until now for the Mediterranean trout of the study area.

\section{CONCLUSIONS}

The main findings of this study highlight that brown trout should be considered native in the southwestern tributaries of the Po River basin. In this area, native brown trout survived the extreme climate phases of Pleistocene. In this respect, the biological value of the south-western Alps for the conservation of the last 
wild native Mediterranean trout population should be considered of primary importance. As a consequence, the non-native statement and the non-intervention approach proposed by the Italian Association of Freshwater Fish Ichthyologists (Zanetti et al., 2013), based on a human conjectural man-mediated origin of Italian slope trout from the Rhône River basin should be rejected. In addition, the weakness of the allochthonous hypothesis is also sustained by the lack of historical records describing the occurrence of such practices in the study area (e.g., Splendiani et al., 2019a).

In conclusion, caution must be exercised when planning conservation actions. For example, elsewhere, in the Italian Alpine region, the massive introduction of domestic Mediterranean brown trout of Apennine origin (AD, ME and MA haplotypes) started in the last five-ten years. In most cases, the outcomes of pivotal genetic screening on local brown trout populations involved in these projects were not published, or even never done. This probably occurred (and still occurs) in Italy because local administrations have transferred to sport fishing associations the fully management of these practices. In these circumstances, the rationale of these putative conservation actions has not been evaluable by the scientific community. Paradoxically, conservation plans can even represent a further threat for the protection of wild native trout. As far as we know, Mediterranean trout hatchery managers in Italy have not published (even considering grey bibliography) the genetic description of their stocks. Recently, the genetic analysis of one of these putative domestic Mediterranean stocks actually turned out as a mix of Mediterranean and Atlantic brown trout (Splendiani et al., 2019b). The irrational planning of massive stocking activities, even if carried out with native brown trout, can introduce further risks related to the potential deleterious genetic effects of supplementation programs (Fernández-Cebrián et al., 2014). These latter ones can result in the breakdown of the delicate equilibrium persisting in the incipient parapatric speciation process subsisting between native brown trout and marble trout, as for example in south-western Alps (Giuffra et al., 1994), and can affect the adaptive genetic architecture of native genomes (Caputo, Giovannotti, Nisi Cerioni, Splendiani, \& Olmo, 2009; Schenekar \& Weiss, 2017). The situation is far better in the French side of the investigated area. In France, more and more administrative organizations, under the supervision of Ecology Ministry, adopted "patrimonial" management during the last twenty years. For this, a large part of the trout populations have been analysed and published in France (https://data.oreme.org/trout/home) with nuclear and mitochondrial markers driving conservation and stocking.

\section{REFERENCES}

Arnold ML. 1997. Natural Hybridization and Evolution. Oxford University Press, Oxford, UK

Bandelt HJ, Forster P \& Rohl A. 1994. Median-Joining Networks for Inferring Intraspecic Phylogenies. Molecular Biology 16: 37-48.

Bernatchez L. 2001. The evolutionary history of brown trout (Salmo trutta L.) inferred from phylogeographic, nested clade, and mismatch analyses of mitochondrial DNA variation. Evolution; international journal of organic evolution 55: 351-79.

Bernatchez L, Guyomard R \& Bonhomme F. 1992. DNA sequence variation of the mitochondrial control region among geographically and morphologically remote European brown trout Salmo trutta populations. Molecular Ecology 1: 161-173.

Bernatchez L \& Danzmann G. 1993. Congruence in control-region sequence and restriction-site variation 16 
in mitochondrial DNA of brook charr (Salvelinus fontinalis Mitchill). Molecular Biology and Evolution 10, 1002-1014.

Berrebi P, Povz M, Jesensek D, Cattaneo-Berrebi G \& Crivelli AJ. 2000. The genetic diversity of native, stocked and hybrid populations of marble trout in the Soca river, Slovenia. Heredity 85: 277-287.

Berrebi P, Caputo Barucchi V, Splendiani A, Muracciole S, Sabatini A, Palmas F, Tougard C, Arculeo M \& Marić S. 2019. Brown trout (Salmo trutta L.) high genetic diversity around the Tyrrhenian Sea as revealed by nuclear and mitochondrial markers. Hydrobiologia 826:209-231.

Berrebi P, Marić S, Snoj A \& Hasegawa K. 2020. Brown trout in Japan -introduction history, distribution and genetic structure. Konoledge and Management of Aquatic Ecosystems 421, 18.

Berrebi P, Jesenšek D \& Crivelli AJ. 2017. Natural and domestic introgressions in the marble trout population of Soča River (Slovenia). Hydrobiologia 785: 277-291.

Brandley MC, Schmitz A \& Reeder TW. 2005. Partitioned Bayesian analyses, partition choice, and the phylogenetic relationships of scincid lizards. Systematic Biology 54: 373-390.

Brown RP \& Yang Z. 2011. Rate variation and estimation of divergence times using strict and relaxed clocks. BMC Evolutionary Biology 11.

Budy P, Thiede GP, Lobón-Cerviá J, Fernandez GG, Mchugh P, Mcintosh A, Voøllestad LA, Becares E \& Jellyman P. 2013. Limitation and facilitation of one of the world's most invasive fish: An intercontinental comparison. Ecology 94: 356-367.

Caputo V, Giovannotti M, Nisi Cerioni P, Splendiani A \& Olmo E. 2009. Chromosomal study of native and hatchery trouts from Italy (Salmo trutta complex, Salmonidae): Conventional and FISH analysis. Cytogenetic and Genome Research 124.

Casalis G. 1833. Dizionario geografico storico-statisticocommerciale degli Stati di S.M. il Re di Sardegna. Vol. I. Torino: Maspero.

Casalis G. 1852. Dizionario geografico storico-statisticocommerciale degli Stati di S.M. il Re di Sardegna. Vol. XXII. Torino:Maspero.

Cortey M \& García-Marín JL. 2002. Evidence for phylogeographically informative sequence variation in the mitochondrial control region of Atlantic brown trout. Journal of Fish Biology 60: 1058-1063.

Cortey M, Pla C \& García-Marín JL. 2004. Historical biogeography of Mediterranean trout. Molecular Phylogenetics and Evolution 33: 831-844.

Cossart E, Braucher R, Fort M, Bourlès DL \& Carcaillet J. 2008. Slope instability in relation to glacial debuttressing in alpine areas (Upper Durance catchment, southeastern France): Evidence from field data and 10Be cosmic ray exposure ages. Geomorphology 95: 3-26.

Estoup A, Largiader CR, Perrot E \& Chourrot D. 1996. Rapid one-tube DNA extraction for reliable PCR detection of fish polymorphic markers and transgenes. Molecular Marine Biology and Biotechnology 5: 295-298.

Excoffier L. 2004. Patterns of DNA sequence diversity and genetic structure after a range expansion: Lessons from the infinite-island model. Molecular Ecology 13: 853-864.

Excoffier L \& Lischer HEL. 2010. Arlequin suite ver 3.5: A new series of programs to perform population genetics analyses under Linux and Windows. Molecular Ecology Resources 10: 564-567.

Fernández-Cebrián R, Araguas RM, Sanz N, García-Marín JL \& Fraser D. 2014. Genetic risks of supplementing trout populations with native stocks: a simulation case study from current Pyrenean populations. Canadian Journal of Fisheries and Aquatic Sciences 71: 1243-1255.

Fernández-García JL, Carranza J, Martínez JG \& Randi E. 2014. Mitochondrial D-loop phylogeny signals two native Iberian red deer (Cervus elaphus) Lineages genetically different to Western and Eastern European red deer and infers human-mediated translocations. Biodiversity and Conservation 23: 537-554.

Fu YX. 1997. Statistical tests of neutrality of mutations against population growth, hitchhiking and background selection. Genetics 147: 915-925.

Gauthier A \& Berrebi P. 2007. La colonisation de l'ile par différentes souches de truite. In: Guide de gestion de la truite macrostigma, 4-10.

Giuffra E, Bernatchez L \& Guyomard R. 1994. Mitochondrial Control Region and Protein-Coding Genes Sequence Variation Among Phenotypic Forms of Brown Trout Salmo-Trutta From Northern Italy. Molecular Ecology 3: 161-171.

Gratton P, Allegrucci G, Sbordoni V \& Gandolfi A. 2014. The evolutionary jigsaw puzzle of the surviving trout (Salmo trutta L. complex) diversity in the italian region. a multilocus bayesian approach. Molecular Phylogenetics and Evolution 79: 292-304.

Habit EM, Walde SJ, Zemlak TS, Ruzzante DE \& Carrea C. 2010. Surviving historical Patagonian 17 
landscapes and climate: molecular insights from Galaxias maculatus. BMC Evolutionary Biology 10: 67. Hayashi K. 1991. PCR-SSCP: A simple and sensitive method for detection of mutations in the genomic DNA. Genome Research 1: 34-38.

Hughes PD, Woodward JC \& Gibbard PL. 2006. Quaternary glacial history of the Mediterranean mountains. Progress in Physical Geography 30: 334-364.

Kottelat M \& Freyhof J (2007) Handbook of european fresh-water fishes. Publications Kottelat, Cornol Larkin MA, Blackshields G, Brown NP, Chenna R, Mcgettigan PA, McWilliam H, Valentin F, Wallace IM, Wilm A, Lopez R, Thompson JD, Gibson TJ \& Higgins DG. 2007. Clustal W and Clustal X version 2.0. Bioinformatics 23: $2947-2948$.

Larson G \& Fuller DQ. 2014. The Evolution of Animal Domestication. Annual Review of Ecology, Evolution, and Systematics 45: 115-136.

Lavery S, Moritz C, \& Fielder DR. 1996. Genetic patterns suggest exponential population growth in a declining species. Molecular Biology and Evolution 13:1106-1113.

Leprieur F, Beauchard O, Blanchet S, Oberdorff T \& Brosse S. 2008. Fish invasions in the world's river systems: When natural processes are blurred by human activities. PLoS Biology 6: 0404-0410.

Losos JB, Arnold SJ, Bejerano G, Brodie ED, Hibbett D, Hoekstra HE, Mindell DP, Monteiro A, Moritz C, Orr HA, Petrov DA, Renner SS, Ricklefs RE, Soltis PS \& Turner TL. 2013. Evolutionary Biology for the 21st Century. PLoS Biology 11(1): 1-8.

Marchetto F, Zaccara S, Muenzel FM \& Salzburger W. 2010. Phylogeography of the Italian vairone (Telestes muticellus, Bonaparte 1837) inferred by microsatellite markers: Evolutionary history of a freshwater fish species with a restricted and fragmented distribution. BMC Evolutionary Biology 10.

Meraner A, Baric S, Pelster B \& Dalla Via J. 2007. Trout (Salmo trutta) mitochondrial DNA polymorphism in the centre of the marble trout distribution area. Hydrobiologia 579: 337-349.

Meraner A, Gratton P, Baraldi F \& Gandolfi A. 2013. Nothing but a trace left? Autochthony and conservation status of Northern Adriatic Salmo trutta inferred from PCR multiplexing, mtDNA control region sequencing and microsatellite analysis. Hydrobiologia 702: 201-213.

Miró A \& Ventura M. 2013. Historical use, fishing management and lake characteristics explain the presence of non-native trout in Pyrenean lakes: Implications for conservation. Biological Conservation 167: $17-24$.

Muñoz M \& Casadevall M. 1997. Fish remains from Arbreda Cave (Serinya Girona), northeast Spain, and their palaeoecological significance. Journal of Quaternary Science 12: 111-115.

Ninua L, Tarkhnishvili D \& Gvazava E. 2018. Phylogeography and taxonomic status of trout and salmon from the Ponto-Caspian drainages, with inferences on European Brown Trout evolution and taxonomy. Ecology and Evolution 8: 2645-2658.

Oliver J. 2014. Evolutionary history of the brown trout, Salmo trutta L., in France. First-year MEME research project Université Montpellier II April-June 2014.

Posada D. 2008. jModelTest: Phylogenetic model averaging. Molecular Biology and Evolution 25: 12531256.

Purvis A \& Hector A. 2000. Getting the measure of biodiversity. Nature 405: 212-219.

Rambaut A, Drummond AJ, Xie D, Baele G \& Suchard MA. 2018. Posterior summarization in Bayesian phylogenetics using Tracer 1.7. Systematic Biology 67: 901-904.

Ramos-Onsins SE \& Rozas J. 2002. Statistical properties of new neutrality tests against population growth. Molecular Biology and Evolution 19: 2092-2100.

Redpath SM, Young J, Evely A, Adams WM, Sutherland WJ, Whitehouse A, Amar A, Lambert RA, Linnell JDC, Watt A \& Gutiérrez RJ. 2013. Understanding and managing conservation conflicts. Trends in Ecology and Evolution 28: 100-109.

Rondinini C, Battistoni A, Peronace V, Teofili (compilatori) C. 2013. Lista Rossa IUCN dei Vertebrati Italiani. Roma: Comitato Italiano IUCN e Ministero dell'Ambiente e della Tutela del Territorio e del Mare.

Rozas J, Ferrer-Mata A, Sanchez-DelBarrio JC, Guirao-Rico S, Librado P, Ramos-Onsins SE \& Sanchez-Gracia A. 2017. DnaSP 6: DNA sequence polymorphism analysis of large data sets. Molecular Biology and Evolution 34: 3299-3302.

Sanz N. 2018. Phylogeographic history of brown trout: A review. In: Lobón Cerviá J, Sanz N, editors. Brown trout: Biology, ecology and management. Hoboken, NJ: John Wiley \& Sons Ltd. pp. 65-102.

Schenekar T, Lerceteau-Köhler E \& Weiss S. 2014. Fine-scale phylogeographic contact zone in Austrian brown trout Salmo trutta reveals multiple waves of post-glacial colonization and a pre-dominance of natural versus anthropogenic admixture. Conservation Genetics 15: 561-572. 
Schenekar T \& Weiss S. 2017. Selection and genetic drift in captive versus wild populations: an assessment of neutral and adaptive (MHC-linked) genetic variation in wild and hatchery brown trout (Salmo trutta) populations. Conservation Genetics 18: 1011-1022.

Shackleton RT, Larson BMH, Novoa A, Richardson DM \& Kull CA. 2019. The human and social dimensions of invasion science and management. Journal of Environmental Management 229: 1-9.

Siccardi S. 1996. Elena la Regina mai dimenticata. Torino: Paoline.

Šlechtová V, Bohlen J, Freyhof J, Persat H \& Delmastro GB. 2004. The Alps as barrier to dispersal in cold-adapted freshwater fishes? Phylogeographic history and taxonomic status of the bullhead in the Adriatic freshwater drainage. Molecular Phylogenetics and Evolution 33: 225-239.

Snoj A, Marić S, Berrebi P, Crivelli AJ, Shumka S \& Sušnik S. 2009. Genetic architecture of trout from Albania as revealed by mtDNA control region variation. Genetics Selection Evolution 41: 22.

Snoj A, Glamuzina B, Razpet A, Zablocki J, Bogut I, Lerceteau-Köhler E, Pojskić N \& Sušnik S. 2010. Resolving taxonomic uncertainties using molecular systematics: Salmo dentex and the Balkan trout community. Hydrobiologia 651: 199-212.

Sønstebø JH, Borgstrøm R \& Heun M. 2007. Genetic structure of brown trout (Salmo trutta L.) from the Hardangervidda mountain plateau (Norway) analyzed by microsatellite DNA: A basis for conservation guidelines. Conservation Genetics 8: 33-44.

Splendiani A, Ruggeri P, Giovannotti M, Pesaresi S, Occhipinti G, Fioravanti T, Lorenzoni M, Nisi Cerioni P \& Caputo Barucchi V. 2016a. Alien brown trout invasion of the Italian peninsula: the role of geological, climate and anthropogenic factors. Biological Invasions 18: 2029-2044.

Splendiani A, Fioravanti T, Giovannotti M, Negri A, Ruggeri P, Olivieri L, Cerioni PN, Lorenzoni M \& Barucchi VC. 2016b. The effects of paleoclimatic events on mediterranean trout: Preliminary evidences from ancient DNA. PLOS ONE 11.

Splendiani A, Fioravanti T, Giovannotti M, Olivieri L, Ruggeri P, Nisi Cerioni P, Vanni S, Enrichetti F \& Caputo Barucchi V. 2017. Museum samples could help to reconstruct the original distribution of Salmo trutta complex in Italy. Journal of Fish Biology 90: 2443-2451.

Splendiani A, Palmas F, Sabatini A \& Caputo V 2019a. The name of the trout: considerations on the taxonomic status of the Salmo trutta L., 1758 complex (Osteichthyes: Salmonidae) in Italy. The European Zoological Journal 86: 432-442.

Splendiani A, Giovannotti M, Righi T, Fioravanti T, Cerioni PN, Lorenzoni M, Carosi A, La Porta G \& Barucchi VC. 2019b. Introgression despite protection: the case of native brown trout in Natura 2000 network in Italy. Conservation Genetics.

Splendiani A, Fioravanti T, Ruggeri P, Giovannotti M, Carosi A, Marconi M, Lorenzoni M, Righi T, Nisi Cerioni $\mathbf{P} \&$ Caputo Barucchi V. 2020. Life history and genetic characterisation of sea trout Salmo trutta in the Adriatic Sea. Freshwater Biology 65: 460-473.

Stefani F, Anzani A \& Marieni A. 2019. Echoes from the past: a genetic trace of native brown trout in the Italian Alps. Environmental Biology of Fishes 102: 1327-1335.

Suchard MA, Lemey P, Baele G, Ayres DL, Drummond AJ \& Rambaut A. 2018. Bayesian phylogenetic and phylodynamic data integration using BEAST 1.10. Virus Evolution 4: 1-5.

Sušnik S, Weiss S, Odak T, Delling B, Treer T \& Snoj A. 2007. Reticulate evolution: Ancient introgression of the Adriatic brown trout mtDNA in softmouth trout Salmo obtusirostris (Teleostei: Salmonidae). Biological Journal of the Linnean Society 90: 139-152.

Szövényi P, Arroyo K, Guggisberg A \& Conti E. 2009. Effects of Pleistocene glaciations on the genetic structure of Saxifraga florulenta (Saxifragaceae), a rare endemic of the Maritime Alps. Taxon 58: 532-543.

Tajima F. 1989. Statistical model for testing the neutral mutation hypothesis by DNA

polymorphism. Genetics 123: 585-595.

Tiberti R \& Splendiani A. 2019. Management of a highly unlikely native fish: The case of arctic charr Salvelinus alpinus from the Southern Alps. Aquatic Conservation: Marine and Freshwater Ecosystems 29: 312-320.

Tougard C, Justy F, Guinand B, Douzery EJP \& Berrebi P. 2018. Salmo macrostigma (Teleostei, Salmonidae): Nothing more than a brown trout (S. trutta) lineage? Journal of Fish Biology 93: 302-310.

Vera M, García-Marín JL, Martinez P \& Bouza C. 2015. Phylogenetic diversity within the endemic brown trout Duero lineage: Implications for conservation and management. Marine and Freshwater Research 66: 1066-1071.

Vera M, Bouza C, Casanova A, Heras S, Martinez P \& García-Marín JL. 2019. Identification of an endemic Mediterranean brown trout mtDNA group within a highly perturbed aquatic system, the Llobregat 19 
River ( NE Spain ). 9: 277-291.

Vonlanthen P, Excoffier L, Bittner D, Persat H, Neuenschwander S \& Largiadèr CR. 2007. Genetic analysis of potential postglacial watershed crossings in Central Europe by the bullhead (Cottus gobio L.). Molecular Ecology 16: 4572-4584.

Waters JM, Craw D, Youngson JH \& Wallis GP. 2001. Genes meet geology: Fish phylogeographic pattern reflects ancient, rather than modern, drainage connections. Evolution 55: 1844-1851.

Zanetti M, Nonnis Marzano F, Lorenzoni M. 2013. I salmonidi italiani: Linee guida per la conservazione della biodiversità. Technical report. Available: http://www.aiiad.it/sito/images/docs/sistematica/GRUPPO\%20DI\%20LAVORO\%20SALMONIDI_RELAZ IONE\%20FINALE.pdf.

Zemlak TS, Habit EM, Walde SJ, Battini MA, Adams EDM \& Ruzzante DE. 2008. Across the southern Andes on fin: Glacial refugia, drainage reversals and a secondary contact zone revealed by the phylogeographical signal of Galaxias platei in Patagonia. Molecular Ecology 17: 5049-5061.

\section{Figure captions}

Figure 1

Map showing the sampling locations of brown trout throughout the Rhône and the western part of the Po River basins. Color pie charts indicate the mtDNA haplotype frequency distribution of the main brown trout lineages. Numbers in bold within pie charts represent the Atlantic haplotype frequency (\%). The distribution of the Alpine ice cover during the last glacial maximum is represented by the light blue area. Box at the top right shows the range of the nominal Mediterranean trout species as reported in Kottelat \& Freyof (2007).

$\dagger$ The geographic range of Salmo cettii according to Kottellat \& Freyhof (2007), \# the revised geographic range of $S$. cettii according to Splendiani et al. (2019b and references therein). Locations code colored differentially based on the river basin of origin.

\section{Figure 2}

Median-Joining Network showing the phylogenetic relationships subsisting between the 18 native brown trout haplotypes detected in this study (colored circles) and the brown trout haplotypes observed in previously published studies (grey circles, see also Table 1; the position of the haplotypes ADcs-11 and ADTyrrh-1 was reported because commented in the text). As regards the haplotypes observed in the study area, the size of each circle is proportional with the haplotype absolute frequency. Locations code colored differentially based on the river basin of origin.

Figure 3

Plot showing the probability density function (density) obtained comparing elevation, longitude and latitude with the mtDNA genetic composition of brown trout populations from the Rhône River basin (A and B) and from the Po River basin (C and $\mathrm{D})$. The mtDNA lineage composition was represented by the following colored scheme: population characterized by the sole presence of ME haplotypes (Pure ME), in green; pure $\mathrm{AD}$ populations, in yellow; admixed AD-ME populations in orange; admixed AD-MA populations, in light blue and marble trout samples (from Giuffra et al., 1994) in blue. To avoid confusion, other minor admixed population were not showed. 


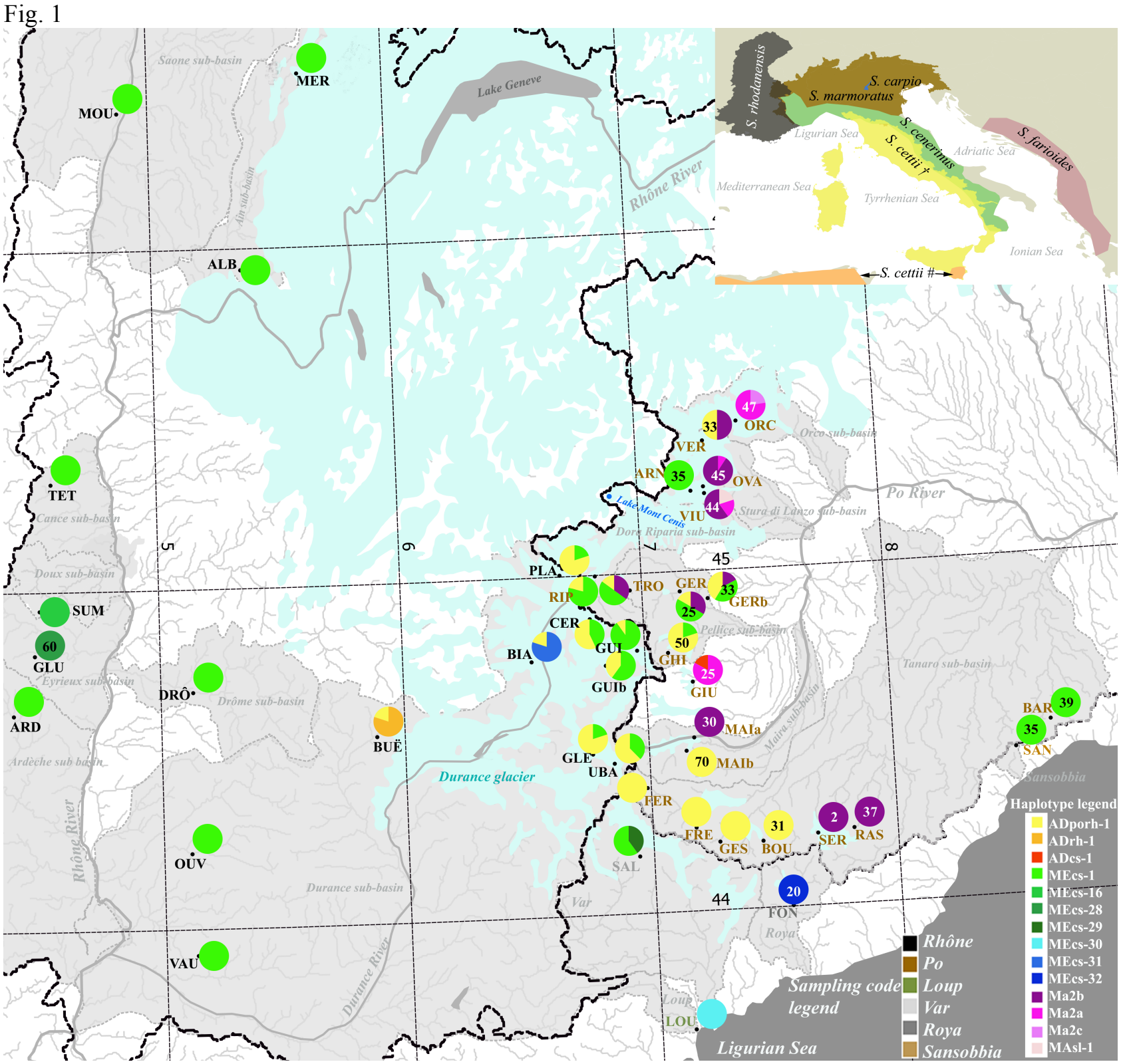




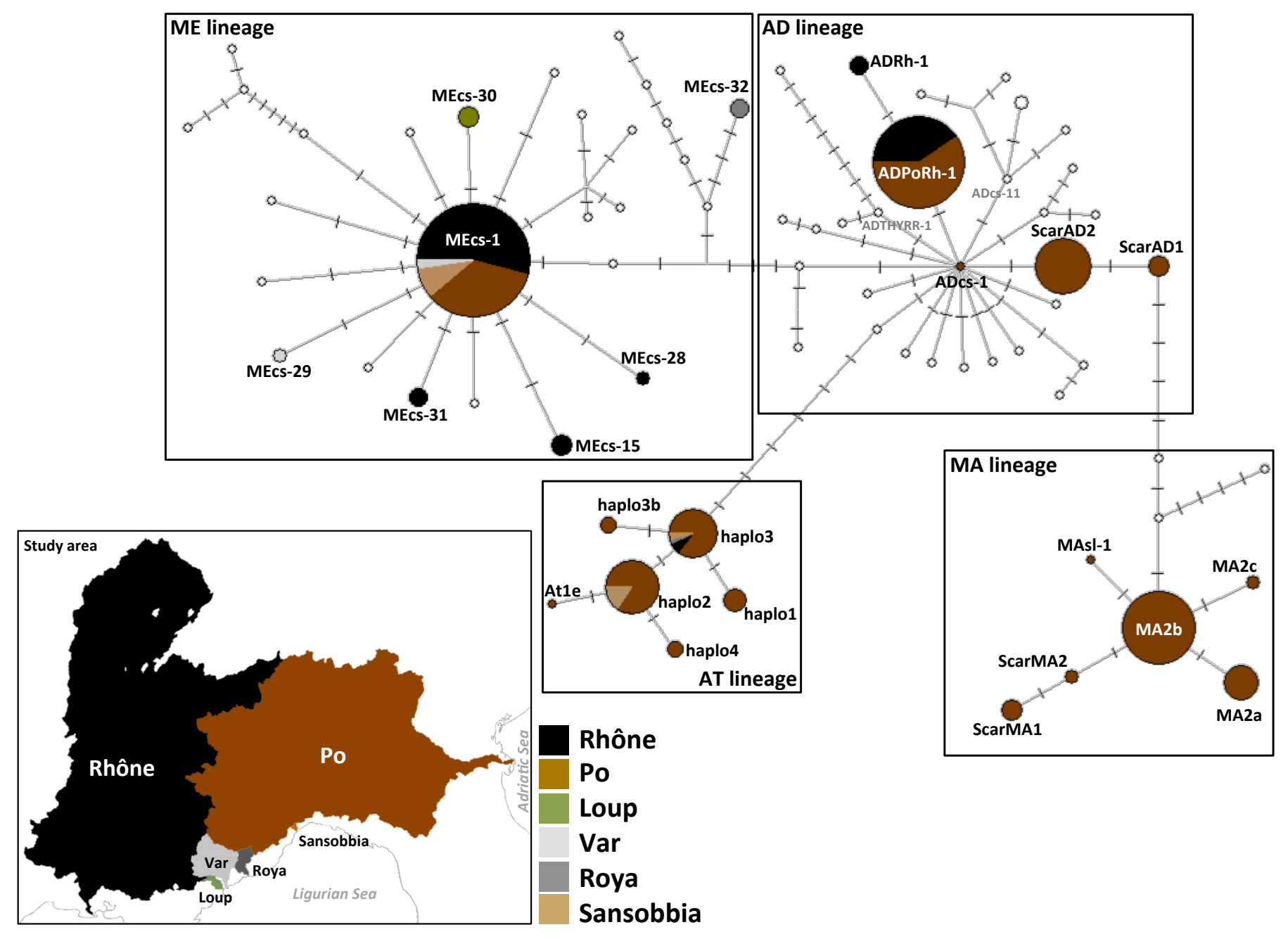


Fig. 3
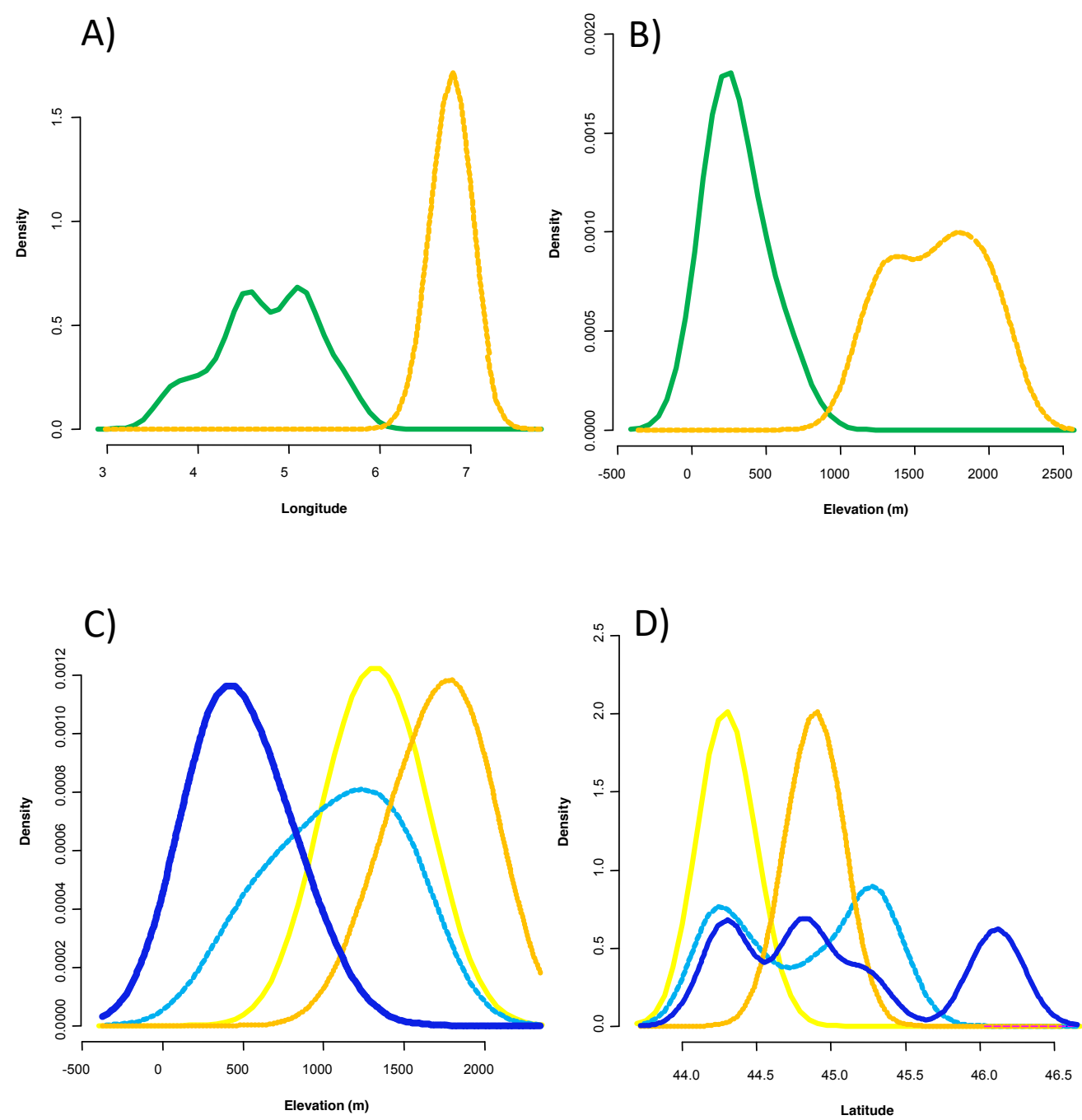


\begin{tabular}{|c|c|c|c|c|c|c|c|c|c|c|}
\hline Code & Taxon & $\begin{array}{c}\text { Sea } \\
\text { drainage }\end{array}$ & $\begin{array}{l}\text { Main- } \\
\text { basin }\end{array}$ & Sub-basin & Stream & No & Lab. & Lat. & Lon. & $\begin{array}{c}\text { Elevatio } \\
\mathrm{n}(\mathrm{m})\end{array}$ \\
\hline MER & S. rod & G & Rhône & Ain & Merlue & 5 & $F$ & 46.51 & 5.64 & 433 \\
\hline MOU & S. rod & G & Rhône & Saône & Mouge & 5 & $\mathrm{~F}$ & 46.40 & 4.87 & 176 \\
\hline ALB & S. rod & G & Rhône & Ain & Albarine & 5 & $\mathrm{~F}$ & 45.94 & 5.38 & 258 \\
\hline ORC & S.cen/S.far & A & Po & Orco & & 17 & 1 & 45.43 & 7.42 & 700 \\
\hline VER & S.cen/S.far & $A$ & Po & Stura di Lanzo & Rio & 18 & I & 45.38 & 7.28 & 1220 \\
\hline TET & S. rod & G & Rhône & Cance & Riotet & 5 & $\mathrm{~F}$ & 45.32 & 4.56 & 668 \\
\hline OVA & S.cen/S.far & A & Po & Stura di Lanzo & Rio & 20 & I & 45.24 & 7.27 & 1480 \\
\hline ARN & S.cen/S.far & $A$ & Po & Stura di Lanzo & Rio Arnas & 10 & I & 45.24 & 7.20 & 1370 \\
\hline VIU & S.cen/S.far & A & Po & Stura di Lanzo & Stura di Viù & 9 & I & 45.23 & 7.28 & 1540 \\
\hline RIP & S.cen/S.far & A & Po & Dora Riparia & Ripa & 24 & I & 45.00 & 6.81 & 1900 \\
\hline PLA & S. rod & G & Rhône & Durance & Clarée & 5 & $\mathrm{~F}$ & 45.00 & 6.66 & 1484 \\
\hline TRO & S.cen/S.far & $A$ & Po & Pellice & Chisone & 20 & I & 44.95 & 6.95 & 1835 \\
\hline GER & S.cen/S.far & A & Po & Pellice & Germanasca & 9 & I & 44.94 & 7.15 & 680 \\
\hline GERb & S.cen/S.far & A & Po & Pellice & Germanasca & 16 & I & 44.92 & 7.27 & 750 \\
\hline CER & S. rod & G & Rhône & Durance & Cerveyrette & 6 & I & 44.87 & 6.78 & 2077 \\
\hline GLU & S. rod & G & Rhône & Eyrieux & Gluyère & 5 & $F$ & 44.81 & 4.48 & 568 \\
\hline GUIb & S. rod & G & Rhône & Durance & Guil & 20 & I & 44.77 & 6.97 & 1779 \\
\hline $\mathrm{GHI}$ & S.cen/S.far & $A$ & Po & Pellice & Ghiacciard & 10 & I & 44.76 & 7.09 & 1440 \\
\hline $\mathrm{BIA}$ & S. rod & G & Rhône & Durance & Biaysse & 5 & $\mathrm{~F}$ & 44.75 & 6.53 & 1200 \\
\hline GUI & S. rod & G & Rhône & Durance & Guil & 5 & $\mathrm{~F}$ & 44.73 & 6.84 & 1693 \\
\hline DRÔ & S. rod & G & Rhône & Drôme & Drôme & 5 & $\mathrm{~F}$ & 44.70 & 5.13 & 229 \\
\hline GIU & S.cen/S.far & $A$ & Po & & Rio Giulian & 10 & I & 44.67 & 7.19 & 1120 \\
\hline ARD & S. rod & G & Rhône & Ardèche & Thines & 5 & $\mathrm{~F}$ & 44.64 & 4.39 & 217 \\
\hline BUË & S. rod & G & Rhône & Durance & Petit Buëch & 5 & $\mathrm{~F}$ & 44.55 & 5.88 & 1117 \\
\hline MAla & S.cen/S.far & $A$ & Po & Maira & Bedale di & 10 & I & 44.51 & 7.18 & 950 \\
\hline BAR & S.cen/S.far & A & Po & Tanaro & Baracca & 18 & I & 44.50 & 8.65 & 570 \\
\hline MAlb & S.cen/S.far & $A$ & Po & Maira & Bedale & 10 & I & 44.47 & 7.15 & 1180 \\
\hline GLE & S. rod & G & Rhône & Durance & Gleizolles & 5 & $F$ & 44.47 & 6.77 & 1319 \\
\hline UBA & S. rod & G & Rhône & Durance & Ubayette & 15 & I & 44.44 & 6.85 & 1953 \\
\hline SAN & S. cet & $\mathrm{L}$ & Sansobbi & & & 20 & I & 44.43 & 8.50 & 660 \\
\hline FER & S.cen/S.far & $A$ & Po & Tanaro & Rio Ferriere & 8 & I & 44.37 & 6.98 & 1480 \\
\hline FRE & S.cen/S.far & $A$ & Po & Tanaro & Rio Freddo & 8 & I & 44.24 & 7.17 & 1550 \\
\hline RAS & S.cen/S.far & $A$ & Po & Tanaro & Rio & 14 & I & 44.22 & 7.82 & 1100 \\
\hline OUV & S. rod & G & Rhône & Ouvèze & Ouvèze & 5 & $F$ & 44.22 & 5.11 & 222 \\
\hline SER & S.cen/S.far & $A$ & Po & Tanaro & Rio & 13 & I & 44.21 & 7.67 & 1280 \\
\hline GES & S.cen/S.far & $A$ & Po & Tanaro & Gesso & 4 & I & 44.20 & 7.27 & 1450 \\
\hline $\mathrm{BOU}$ & S.cen/S.far & $A$ & Po & Tanaro & Bousset & 13 & I & 44.20 & 7.45 & 1170 \\
\hline SAL & $?$ & G & Var & Tinée & Tinée & 5 & $\mathrm{~F}$ & 44.17 & 6.94 & 1930 \\
\hline FON & $?$ & $\mathrm{G}$ & Roya & Roya & Roya & 5 & $\mathrm{~F}$ & 44.00 & 7.55 & 426 \\
\hline SUM & S. rod & G & Rhône & Doux & Sumène & 5 & $\mathrm{~F}$ & 43.98 & 3.72 & 203 \\
\hline VAU & S. rod & G & Rhône & Ouvèze & Sorgue & 5 & $\mathrm{~F}$ & 43.92 & 5.13 & 89 \\
\hline LOU & $?$ & $\mathrm{G}$ & Loup & Loup & Loup & 5 & $\mathrm{~F}$ & 43.65 & 7.13 & 7 \\
\hline
\end{tabular}


Table 2. Haplotype frequency distribution at mtDNA control region in wild brown trout populations from the Rhône, Po and other neighbour Mediterranean rivers. Sampling code as in Table 1.

\begin{tabular}{|c|c|c|c|c|c|c|c|c|c|c|c|c|c|c|c|c|c|c|c|c|c|}
\hline Code & Basin & $\begin{array}{l}\overrightarrow{\tilde{u}} \\
\stackrel{\mathrm{W}}{\Sigma}\end{array}$ & 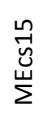 & 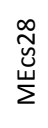 & 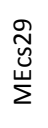 & 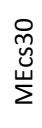 & $\begin{array}{l}\overrightarrow{\tilde{m}} \\
\stackrel{\breve{山}}{\Sigma}\end{array}$ & 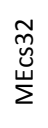 & 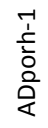 & $\frac{\vec{t}}{\frac{1}{5}}$ & $\begin{array}{l}\overrightarrow{\breve{d}} \\
\text { 安 }\end{array}$ & $\stackrel{\stackrel{0}{N}}{\stackrel{\Sigma}{\Sigma}}$ & 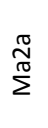 & $\stackrel{\stackrel{N}{\Sigma}}{\sum}$ & $\frac{\frac{1}{1}}{\sum}$ & $\frac{\overrightarrow{0}}{\pi}$ & 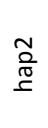 & $\begin{array}{l}m \\
\stackrel{2}{0} \\
\stackrel{0}{\pi}\end{array}$ & $\begin{array}{l}\frac{T}{\pi} \\
\stackrel{\frac{0}{\pi}}{\pi}\end{array}$ & 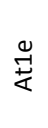 & $\begin{array}{l}\stackrel{0}{m} \\
\stackrel{0}{\pi} \\
\stackrel{\Gamma}{\Gamma}\end{array}$ \\
\hline MER & Rhône & 5 & & & & & & & & & & & & & & & & & & & \\
\hline MOU & Rhône & 5 & & & & & & & & & & & & & & & & & & & \\
\hline ALB & Rhône & 5 & & & & & & & & & & & & & & & & & & & \\
\hline ORC & Po & & & & & & & & & & & & 7 & 2 & & & 5 & & & & 3 \\
\hline VER & Po & & & & & & & & 6 & & & 6 & & & & 6 & & & & & \\
\hline TET & Rhône & 5 & & & & & & & & & & & & & & & & & & & \\
\hline OVA & Po & & & & & & & & & & & 10 & 1 & & & & 9 & & & & \\
\hline ARN & Po & 3 & & & & & & & & & & 2 & & & & & 1 & 4 & & & \\
\hline VIU & Po & . & & & & & & & & & & 3 & 1 & & 1 & & 3 & 1 & & & \\
\hline PLA & Rhône & 1 & & & & & & & 4 & & & & & & & & & & & & \\
\hline RIP & Po & 19 & & & & & & & 5 & & & & & & & & & & & & \\
\hline TRO & Po & 10 & & & & & & & 3 & & & 7 & & & & & & & & & \\
\hline GER & Po & 3 & & & & & & & 1 & & & 2 & & & & & & 3 & & & \\
\hline GERb & Po & 5 & & & & & & & 5 & & & 2 & & & & & 2 & & 1 & 1 & \\
\hline CER & Rhône & 9 & & & & & & & 11 & & & & & & & & & & & & \\
\hline GLU & Rhône & & & 2 & & & & & & & & & & & & & & 3 & & & \\
\hline GUIb & Rhône & 18 & & & & & & & 2 & & & & & & & & & & & & \\
\hline $\mathrm{GHI}$ & Po & 1 & & & & & & & 4 & & & & & & & & & 4 & 1 & & \\
\hline BIA & Rhône & & & & & & 4 & & 1 & & & & & & & & & & & & \\
\hline GUI & Rhône & 3 & & & & & & & 2 & & & & & & & & & & & & \\
\hline DRÔ & Rhône & 5 & & & & & & & & & & & & & & & & & & & \\
\hline GIU & Po & & & & & & & & & & 1 & & 5 & & & & 2 & 2 & & & \\
\hline ARD & Rhône & 5 & & & & & & & & & & & & & & & & & & & \\
\hline BUË & Rhône & & & & & & & & 1 & 4 & & & & & & & & & & & \\
\hline MAla & Po & & & & & & & & & & & 7 & & & & & & 3 & & & \\
\hline BAR & Po & 11 & & & & & & & & & & & & & & & & 7 & & & \\
\hline GIE & Rhône & 1 & & & & & & & 4 & & & & & & & & & & & & \\
\hline MAlb & Po & & & & & & & & 3 & & & & & & & & 1 & 5 & 1 & & \\
\hline UBA & Rhône & 8 & & & & & & & 13 & & & & & & & & & & & & \\
\hline SAN & Sansob. & 13 & & & & & & & & & & & & & & & 6 & 1 & & & \\
\hline FER & Po & & & & & & & & 8 & & & & & & & & & & & & \\
\hline FRE & Po & & & & & & & & 8 & & & & & & & & & & & & \\
\hline OUV & Rhône & 5 & & & & & & & & & & & & & & & & & & & \\
\hline RAS & Po & & & & & & & & & & & 10 & & & & & 4 & & & & \\
\hline SER & Po & & & & & & & & & & & 12 & & & & & & 0 & & & \\
\hline GES & Po & & & & & & & & 4 & & & & & & & & & & & & \\
\hline $\mathrm{BOU}$ & Po & & & & & & & & 9 & & & & & & & & 4 & & & & \\
\hline SAL & Var & 3 & & & 2 & & & & & & & & & & & & & & & & \\
\hline FON & Roya & & & & & & & 4 & & & & & & & & & & 1 & & & \\
\hline SUM & Rhône & & 5 & & & & & & & & & & & & & & & & & & \\
\hline VAU & Rhône & 5 & & & & & & & & & & & & & & & & & & & \\
\hline LOU & Loup & & & & & 5 & & & & & & & & & & & & & & & \\
\hline
\end{tabular}


Gratton P, Allegrucci G, Sbordoni V, Gandolfi A. 2014. The evolutionary jigsaw puzzle of the surviving trout (Salmo trutta L. complex) diversity in the Italian region. A multilocus Bayesian approach. Molecular Phylogenetics and Evolution79:292-304. DOI: 10.1016/j.ympev.2014.06.022.

Kottelat M, Freyhof J. 2007. Handbook of European fresh-water fishes. Publications Kottelat, Cornol

Lerceteau-Köhler E, Schliewen U, Kopun T, Weiss S. 2013. Genetic variation in brown trout Salmo trutta across the Danube, Rhine, and Elbe headwaters: A failure of the phylogeographic paradigm? BMC Evolutionary Biology 13:176.

Marić S, Sušnik S, Schöffmann J, Kostov V, Snoj A. 2017. Phylogeography of stream-dwelling trout in the Republic of Macedonia and a molecular genetic basis for revision of the taxonomy proposed by S. Karaman. Hydrobiologia 785:249-260.

Meraner A, Gandolfi A. 2018. Genetics of the genus Salmo in Italy: Evolutionary history, population structure, molecular ecology and conservation. In: Lobón-Cerviá J, Sanz N, editors. Brown trout: Biology, ecology and management.Hoboken, NJ: John Wiley \& Sons Ltd. pp. 65-102.

Sabatini A, Cannas R, Follesa MC, Palmas F, Manunza A, Matta GA, Pendugiu A, Serra P, Cau A. 2011. Genetic characterization and artificial reproduction attempt of endemic

Sardinian trout Salmo trutta L., 1758 (Osteichthyes, Salmonidae): Experiences in captivity. Italian Journal of Zoology 78:20-26. DOI: 10.1080/11250003.2010.497171.

Schöffmann J, Sušnik S, Snoj A. 2007. Phylogenetic origin of Salmo trutta L 1758 from Sicily, based on mitochondrial and nuclear DNA analyses. Hydrobiologia 575:51-55.

Snoj A, Marić S, Sušnik Bajec S, Berrebi P, Janjani S, Schöffmann J. 2011. Phylogeographic structure and demographic patterns of brown trout in North-West Africa.

Molecular Phylogenetics and Evolution 61:203-211.

Splendiani A, Giovannotti M, Nisi Cerioni P, Caniglia ML, Caputo V. 2006. Phylogeographic inferences on the native brown trout mtDNA variation in central Italy. Italian Journal of Zoology 72:179-189.

Splendiani A, Giovannotti M, Caniglia ML, Nisi Cerioni P, Battistella S, Caputo V. 2007. Presenza di aplotipi "marmoratus" in popolazioni di trota fario (Salmo trutta L., 1758) dell'Italia centrale: Transfaunazione o paleointrogressione? Atti Del Congresso Congiunto AIOL-SItE 2007:89-93.

Splendiani A, Fioravanti T, Giovannotti M, Olivieri L, Ruggeri P, Nisi Cerioni P, Vanni S, Enrichetti F, Caputo Barucchi V. 2017. Museum samples could help to reconstruct the original distribution of Salmo trutta complex in Italy. Journal of Fish Biology 90:2443-2451.

Tougard C, Justy F, Guinand B, et al. 2018. Salmo macrostigma (Teleostei, Salmonidae): Nothing more than a brown trout (S. trutta) lineage? Journal of Fish Biology 93:302310 .

Zaccara S, Trasforini S, Antognazza CM, Puzzi C, Robert Britton J, Crosa G. 2015. Morphological and genetic characterization of Sardinian trout Salmo cettii Rafinesque, 1810 and their conservation implications. Hydrobiologia 760:205-223. 
Table S2: List of haplotypes retrieved from GenBank, with accession numbers and their distributions.

\begin{tabular}{|c|c|c|}
\hline Haplotype & $\begin{array}{c}\text { Accession } \\
\text { number }\end{array}$ & Distribution - country/drainages \\
\hline haplotype 1 (ATcs1) & AF273086 & $\begin{array}{l}{ }^{2} \text { Denmark (Skals), Norway (Bjornes Lake, Sima), Spain (hatchery } \\
\text { stocks), }{ }^{4} \text { Spain (Garona), France (Gulf of Biscay), Iceland } \\
\text { (Skorradalsvatn), British Isles (Coquet, Wear, Lune, Melvin), } \\
{ }^{11} \text { continental Italy (IT), Sardinia, Corsica }\end{array}$ \\
\hline haplotype 2 (ATcs2) & AF273087 & $\begin{array}{l}{ }^{2} \text { Denmark (Skals, Karup), Norway (Guddal, Sima), Spain (hatchery } \\
\text { stocks), }{ }^{5} \text { France (Gulf of Biscay), British Isles (Coquet, Stour, Rother, } \\
\text { Fowey, Teifi, Conwy, Loch Romoch), Russia (Nilima, Vorobiev), } \\
{ }^{11} \text { Sardinia, Corsica }\end{array}$ \\
\hline haplotype 3 (ATcs3) & AF274574 & $\begin{array}{l}{ }^{2} \text { Denmark (Skals), Norway (Bjornes Lake, Guddal, Sima), Spain } \\
\text { (hatchery stocks), }{ }^{4} \text { Spain (Garona), France (Gulf of Biscay), British } \\
\text { Isles (Coquet, Wear, Rother, Teifi, Conwy, Melvin), }{ }^{11} \text { continental } \\
\text { Italy, Sardinia, Calabria }\end{array}$ \\
\hline haplotype 4 (ATcs4) & AF274575 & $\begin{array}{l}{ }^{2} \text { Denmark (Skals, Karup), Norway (Bjornes Lake, Guddal, Sima), } \\
\text { Spain (hatchery stocks), }{ }^{4} \text { France (Gulf of Biscay), British Isles } \\
\text { (Lune), }{ }^{11} \text { Sardinia, Calabria }\end{array}$ \\
\hline Hap3b & MK948037 & ${ }^{20}$ Italy (Po) \\
\hline At1e & DQ841192 & ${ }^{8}$ Italy (Adige), ${ }^{20}$ Italy (Po) \\
\hline ADcs 1 & AY836330 & $\begin{array}{l}{ }^{3} \text { Spain (Ter, Ebre, Túria, Segura), }{ }^{6} \text { Bulgaria (Struma, Mesta, } \\
\text { Maritza), }{ }^{1,7} \text { Macedonia (Prespa Lake, Vardar), }{ }^{20} \text { Italy }(\mathrm{Po})\end{array}$ \\
\hline ADcs2 & AY836331 & ${ }^{3}$ Spain (Guadalfeo) \\
\hline $\mathrm{ADcs} 3$ & AY836332 & ${ }^{3}$ Spain (Ebre) \\
\hline ADcs4 & AY836333 & ${ }^{3}$ Spain (Ter) \\
\hline ADcs5 & AY836334 & ${ }^{3}$ Spain (Guadalfeo) \\
\hline ADcs6 & AY836335 & ${ }^{3}$ Spain (Ebre, Guadalfeo) \\
\hline ADcs 7 & AY836336 & ${ }^{3}$ Spain (Ebre) \\
\hline $\mathrm{ADcs} 8$ & AY836337 & ${ }^{3}$ Spain (Ebre) \\
\hline ADcs9 & AY836338 & ${ }^{3}$ Spain (Turia) \\
\hline ADcs 10 & AY836339 & ${ }^{3}$ Spain (Guadalfeo) \\
\hline ADcs11 & AY836340 & $\begin{array}{l}{ }^{3} \text { Greece (Alfios), }{ }^{10} \text { Montenegro (Skadar Lake), }{ }^{12} \text { Albania (Drin, } \\
\text { Skumbini, Cermit), }{ }^{13} \text { Montengro (Zeta, Morača, Cijevna) }\end{array}$ \\
\hline ADcs15 & AY836344 & ${ }^{4}$ France - Corsica (Corsica stream) \\
\hline ADcs16 & AY836345 & ${ }^{3}$ Spain (Ebre) \\
\hline ADcs17 & AY836346 & ${ }^{3}$ Spain (Ebre) \\
\hline ADcs 18 & AY836347 & ${ }^{3}$ Spain (Guadalquivir) \\
\hline ADcs19 & AY836348 & ${ }^{3}$ Spain (Guadalquivir) \\
\hline ADcs20 & AY836349 & ${ }^{3}$ Greece (Tripotamos), ${ }^{13}$ Bulgaria (Maritza) \\
\hline ADporh-1 & MK948034 & ${ }^{20}$ France (Rhône), Italy (Po) \\
\hline ADrh-1 & MK948035 & ${ }^{20}$ France (Rhône) \\
\hline AD-Tyrrh1 & KX450257 & ${ }^{11}$ Corsica, Sardinia, Calabria, continental Italy (Aniene River) \\
\hline AD-Tyrrh2 & KX450258 & ${ }^{11}$ Corsica, continental Italy (Aniene River) \\
\hline AD-Tyrrh3 & KX450259 & ${ }^{11}$ Calabria (Diga Giulia River) \\
\hline
\end{tabular}




\begin{tabular}{|c|c|c|}
\hline AD-Tyrrh4 & KX450260 & ${ }^{11}$ Sardinia, continental Italy (Aniene River) \\
\hline AD-Tyrrh5 & KX450261 & 11 continental Italy (Nera River) \\
\hline AD-Tyrrh6 & KX450262 & 11 continental Italy (Nera River) \\
\hline AD-zls-01 & MG194729 & ${ }^{15}$ Italy (Liri) \\
\hline AD-zls-01 & MG194729 & ${ }^{15}$ Italy (Liri) \\
\hline ScarAD-1 (C208) & KJ834848 & ${ }^{16}$ Italy (Garda Lake) \\
\hline ScarAD-2 (C021) & KJ834822 & ${ }^{16}$ Italy (Garda Lake) \\
\hline MEcs1 & AY836350 & $\begin{array}{l}{ }^{3} \text { Spain (Ter, Llobregat, Ebre, Míjares, Palancia, Túria, Segura), } \\
{ }^{5} \text { Croatia (Krka), }{ }^{20} \text { France (Rhône, Var), Italy (Po, Sansobbia) }\end{array}$ \\
\hline MEcs4 & AY836353 & ${ }^{3}$ Spain $($ Ter) \\
\hline MEcs6 & AY836355 & ${ }^{3}$ Spain (Ebre) \\
\hline MEcs7 & AY836356 & ${ }^{3}$ Spain $($ Ter) \\
\hline MEcs8 & AY836357 & ${ }^{3}$ Spain (Túria) \\
\hline MEcs9 & AY836358 & ${ }^{3}$ Spain (Túria) \\
\hline MEcs10 & AY836359 & ${ }^{3}$ Spain (Ebre) \\
\hline MEcs11 & AY836360 & ${ }^{3}$ Spain (Túria) \\
\hline MEcs12 & AY836361 & ${ }^{3}$ Spain $($ Ter $)$ \\
\hline MEcs13 & AY836362 & ${ }^{3}$ Spain (Ebre) \\
\hline MEcs14 & AY836363 & ${ }^{3}$ Spain (Ebre, Guadalfeo) \\
\hline MEcs15 & AY836364 & ${ }^{3}$ Spain (Ebre), ${ }^{20}$ France (Rhône) \\
\hline MEcs16 & unpublished & ${ }^{17}$ Spain \\
\hline MEcs17 & unpublished & ${ }^{17}$ Spain \\
\hline MEcs 18 & unpublished & ${ }^{17}$ Spain \\
\hline MEcs20 & unpublished & ${ }^{17}$ Spain \\
\hline MEcs21 & unpublished & ${ }^{17}$ Spain \\
\hline MEcs22 & unpublished & ${ }^{17}$ Spain \\
\hline MEcs23 & MG970273 & ${ }^{18}$ Spain (Cardener) \\
\hline MEcs25 & MG970274 & ${ }^{18}$ Spain (Cardener) \\
\hline MEcs26 & MG970275 & ${ }^{18}$ Spain (Cardener) \\
\hline MEcs27 & MG970276 & ${ }^{18}$ Spain (Cardener) \\
\hline MEcs 28 & MK948029 & ${ }^{20}$ France (Rhône) \\
\hline MEcs29 & MK948030 & ${ }^{20}$ France (Var) \\
\hline$M E \operatorname{cs} 30$ & MK948031 & ${ }^{20}$ France (Loup) \\
\hline MEcs31 & MK948032 & ${ }^{20}$ France (Rhône) \\
\hline MEcs32 & MK948033 & ${ }^{20}$ France (Roya) \\
\hline ME-nin63 & MG194732 & ${ }^{15}$ Italy (Sisto) \\
\hline MAcs1 & AY836365 & ${ }^{3}$ Slovenia (Soča), ${ }^{6}$ Greece (Aliakmon), ${ }^{8}$ Italy (Adige), Italy (Po) \\
\hline $\mathrm{Ma} 2 \mathrm{a}$ & DQ841189 & ${ }^{8}$ Italy (Adige), ${ }^{20}$ North Italy (Po) \\
\hline $\mathrm{Ma} 2 \mathrm{~b}$ & DQ841190 & ${ }^{8}$ Italy (Adige), ${ }^{20}$ North Italy (Po) \\
\hline $\mathrm{Ma} 2 \mathrm{c}$ & JQ582461 & ${ }^{9}$ Italy (Adige), ${ }^{20}$ North Italy (Po) \\
\hline ScarMA1 (C201) & KJ834841 & ${ }^{16}$ Italy (Garda Lake) \\
\hline
\end{tabular}




\begin{tabular}{|l|l|l|}
\hline ScarMA2 (C024) & KJ834825 & ${ }^{16}$ Italy (Garda Lake) \\
\hline marm1 & KJ834770 & ${ }^{16}$ North Italy (Po, Adige), Slovenia (Soca River) \\
\hline Mak1 & JX846931 & ${ }^{19}$ Croatia (Krka) \\
\hline MAsl-1 & MK948036 & ${ }^{20}$ North Italy (Po) \\
\hline
\end{tabular}

${ }^{1}$ Berrebi, P., Tougard, C., Dubois, S., Shao, Zh., Koutseri, I., Petkovski, S. \& Crivelli, A. J. 2013. Genetic diversity and conservation of the Prespa trout in the Balkans. International Journal of Molecular Sciences 14: 23454-23470.

${ }^{2}$ Cortey, M. \& García-Marín, J. L. 2002. Evidence for phylogeographically informative sequence variation in the mitochondrial control region of Atlantic brown trout. Journal of Fish Biology 60: 1058-1063.

${ }^{3}$ Cortey, M., Pla, C. \& García-Marín, J. L. 2004. Historical biogeography of Mediterranean trout. Molecular Phylogenetics and Evolution 33: 831-844.

${ }^{4}$ Cortey, M., Vera, M., Pla, C. \& García-Marín, J. L., 2009. Northern and Southern expansions of Atlantic brown trout (Salmo trutta) populations during the Pleistocene. Biological Journal of the Linnean Society 97: 904-917.

${ }^{5}$ Jadan, M., Strunjak-Perović, I., Topić Popović, N. \& Čož-Rakovac, R. 2015. Three major phylogenetic lineages of brown trout (Salmo trutta Linnaeus, 1758) in the Krka River system (Croatia) revealed by complete mitochondrial DNA control region sequencing. Journal of Applied Ichthyology 31: 192-196.

${ }^{6}$ Kohout, J., Šedivá, A., Apostolou, A., Stefanov, T., Marić, S., Gaffaroğlu, M. \& Šlechta, V. 2013. Genetic diversity and phylogenetic origin of brown trout Salmo trutta populations in eastern Balkans. Biologia 68: 1229-1237.

${ }^{7}$ Marić, S., Sušnik Bajec, S., Schöffmann, J., Kostov, V. \& Snoj, A. (2017). Phylogeography of stream-dwelling trout in the Republic of Macedonia and a molecular genetic basis for revision of the taxonomy proposed by S. Karaman. Hydrobiologia 785: 249-260.

${ }^{8}$ Meraner, A., Baric, S., Pelster, B. \& Dalla-Via, J. 2007. Trout (Salmo trutta) mitochondrial DNA polymorphism in the centre of the marble trout distribution area. Hydrobiologia 579: 337-349.

${ }^{9}$ Meraner, A., Gratton, P., Baraldi, F. \& Gandolfi, A. 2013. Nothing but a trace left? Autochthony and conservation status of Northern Adriatic Salmo trutta inferred from PCR multiplexing, mtDNA control region sequencing and microsatellite analysis. Hydrobiologia 702: 201-213.

${ }^{10}$ Sušnik, S., Snoj, A., Wilson, I. F., Mrdak, D. \& Weiss, S. 2007. Historical demography of brown trout (Salmo trutta) in the Adriatic drainage including the putative S. letnica endemic to Lake Ohrid. Molecular Phylogenetics and Evolution 44: 63-76.

${ }^{11}$ Berrebi P, Caputo Barucchi V, Splendiani A, Muracciole S, Sabatini A, Palmas F, Tougard C, Arculeo M, Maric S (2019) Brown trout (Salmo trutta L.) high genetic diversity around the Tyrrhenian Sea as revealed by nuclear and mitochondrial markers. Hydrobiologia 826:209-231.

12 Snoj, A., S. Marić, P. Berrebi, A. Crivelli, S. Shumka \& S. Sušnik, 2009. Genetic architecture of trout from Albania as revealed by mtDNA control region variation. Genetics Selection Evolution, 41: 22

13 Snoj, A., Glamuzina, B., Razpet, A., Zablocki, J., Bogut, I., Lerceteau-Köhler, E., Pojskić , N., Sušnik, S., 2010. Resolving taxonomic uncertainties using molecular systematics: Salmo dentex and the Balkan trout community. Hydrobiologia 651, 651, 199212.

${ }^{14}$ Kohout J., Šedivá A., Apostolou A., Stefanov T., Marić S., Gaffaroğlu M., et al. (2013). Genetic diversity and phylogenetic origin of brown trout Salmo trutta populations in eastern Balkans. Biologia, 68, 1229-1237.

${ }^{15}$ Fabiani A, Gratton P, Zappes IA, Seminara M, D’Orsi A, Sbordoni V, Allegrucci G (2018) Investigating the genetic structure of trout from the Garden of Ninfa (central Italy): suggestions for conservation and management. Fishery Management and Ecology 25:1-11.

${ }^{16}$ Gratton, P., Allegrucci, G., Sbordoni, V. \& Gandolfi, A. (2014). The evolutionary jigsaw puzzle of the surviving trout (Salmo trutta L. complex) diversity in the Italian region. A multilocus Bayesian approach. Molecular Phylogenetics and Evolution 79, $292-304$.

${ }^{17}$ Vera, M. (2006). Estudio de las variaciones espaciales y temporales de la diversidad genética de la trucha común, Salmo trutta, en ríos de la Península Ibérica. PhD thesis, Girona, 22 de Marzo de 2006.

${ }^{18}$ Vera, M., Bouza, A., Casanova, S., Heras, P., Martínez, J., García-Marín, L. (2019). Identification of an endemic Mediterranean brown trout mtDNA group within a highly perturbed aquatic system, the Llobregat River (NE Spain). Hydrobiologia 827, $277-291$.

19 Jadan, M., Strunjak-Perović, I., Topić Popović, N. \& Čož-Rakovac, R. (2015). Three major phylogenetic lineages of brown trout (Salmo trutta Linnaeus, 1758) in the Krka River system (Croatia) revealed by complete mitochondrial DNA control region sequencing. Journal of Applied Ichthyology, 31, 192-196.

${ }^{20}$ Present study (new haplotypes) 
Table S3. Demographic indices calculated for three brown trout mtDNA lineages based on control region sequence analysis.

\begin{tabular}{|c|c|c|c|c|c|c|}
\hline & \multicolumn{3}{|c|}{ Neutrality test } & \multicolumn{2}{c|}{ Mismatch analysis } & Model \\
\hline & Fs & $\mathbf{D}$ & $\mathbf{R}_{\mathbf{2}}$ & SSD & $\mathbf{r}$ & \\
\hline ME & $-\mathbf{2 . 8 7 4 *}$ & $\mathbf{- 1 . 8 9 7 *}$ & $\mathbf{0 . 1 2 4} * * *$ & $\mathbf{0 . 0 2 7} * *$ & $\mathbf{0 . 0 6 6 *}$ & Expansion \\
\hline AD & -2.126 & $-\mathbf{2 . 1 4 7} *$ & $\mathbf{0 . 1 2 1} * * *$ & $\mathbf{0 . 0 2 3} * *$ & $\mathbf{0 . 0 7 6 * *}$ & Expansion \\
\hline MA & -1.019 & -1.070 & $\mathbf{0 . 1 8 8 * * *}$ & 0.039 & 0.111 & Stable \\
\hline
\end{tabular}

Fs = Fu's F statistic, D = Tajima's D statistic, R2 = Ramos-Osisns and Rozas statistic, SSD = sum of standard deviations of mismatch distribution, $r=$ raggedness index of mismatch distribution. ${ }^{* * *} p<0.001, * * p<0.01, * p<0.05$.

\begin{tabular}{|c|c|c|c|c|}
\hline Substitution rate (\%) & Node & TMRCA (MY) & Lower 95\% HPD (MY) & Upper 95\% HPD (MY) \\
\hline \multirow{4}{*}{0.75} & ADporh1-ADrh1 & 0.151 & 0.011 & 0.099 \\
\cline { 2 - 5 } & AD & 0.278 & 0.170 & 0.391 \\
\cline { 2 - 5 } & ME & 0.267 & 0.166 & 0.372 \\
\cline { 2 - 5 } & MA & 0.122 & 0.172 & 0.205 \\
\hline \multirow{4}{*}{1} & ADporh1-ADrh1 & 0.120 & 0.016 & 0.086 \\
\cline { 2 - 5 } & AD & 0.212 & 0.129 & 0.298 \\
\cline { 2 - 5 } & ME & 0.191 & 0.122 & 0.265 \\
\cline { 2 - 5 } & MA & 0.117 & 0.051 & 0.193 \\
\hline
\end{tabular}

Table S4. Time to the most common ancestor (TMRCA) estimates for the Mediterranean brown trout lineages $A D, M E$ and MA and for the sub-clade ADporh-1, ADrh-1 with 95\% highest probability density (HPD) intervals. 